Dn Truman Mrichelen, mith the compliment of Sohn R. Snentom

Haida sorgs 

PM
1274
$8972 a$
1912
SCNHEB

\title{
HAIDA SONGS
}

\author{
BY \\ John R. Swanton.
}

I-PUBL. AMER. ETHN. SOC. VOL. III. 



\section{INTRODUCTION.}

TuE following songs were collected by the writer in connection with his work for the Jesup North Pacific Expedition during the winter of I900-OI. The general characteristics of the songs were described in "Contributions to the Ethnology of the Haida" (Publications of the Jesup North Pacific Expedition, Vol. V, p. I 2 I). As has been stated in a discussion of the songs, the cradle-songs are the property of the various families. For this reason the songs which form the bulk of the collection here presented are arranged according to the families to which they belong. The names of the families will also be found in the publication before referred to.

The following alphabet is used for rendering Haida songs : -

EXPLANATION OF ALPHABET USED IN RENDERING INDIAN SOUNDS.

$$
\begin{aligned}
& \text { i e, î, a, ô, ou } \\
& \bar{i} \bar{e}, \quad \ddot{a}, \quad \bar{a}, \quad(\hat{a}), \quad \bar{o} \bar{u}
\end{aligned}
$$

A obscure $a$.

i, e, are probably the same sound, intermediate between the continental values of $i$ and $e$.

$\hat{\imath}=i$ in hill.

a has its continental value.

$o$, $u$, are probably the same sound, intermediate between the continental values of 0 and $u$.

$\ddot{a}=$ German $\ddot{a}$ in $B \ddot{a} r$.

$\hat{a}=a z e$ in laze, only in foreign words.

a o $u$ indicate that the preceding consonant is pronounced with $a, o$, and $u$ position of the mouth respectively. 


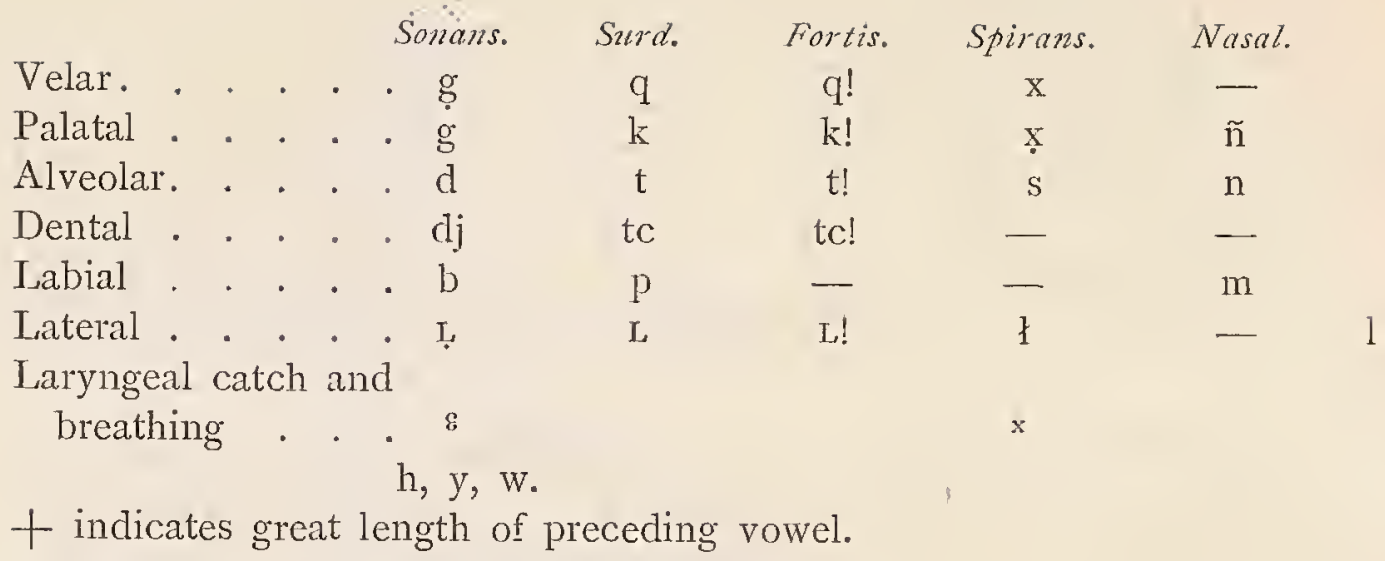

I have omitted the anterior palatal series, because the Haida sounds which should be classed under that head seem to me accidentally produced, owing to the presence of a following close vowel. $p$ seems to occur only in onomatopoetic elements; $b$ occurs not more than two or three times in strictly Haida words; and $m$, although considerably more abundant, is by no means common. The catch $\left(^{(}\right)$is used in Masset instead of Skidegate $g$ and $x$ instead of Skidegate $x . x$ is like German $c h$ in Bach; $x$ is similar, but pronounced farther forward. Even among old people the fortis-sounds are frequently reduced to simple pauses. This is particularly true of sounds formed far forward in the mouth. At other times they are uttered with rapidity and force. In recording my texts, I found it difficult to distinguish fortis-sounds from sonants. I sounds something like $d l$, and $\mathrm{L}$ something like $t l$ or $\mathrm{kl}$; in both the tip of the tongue touches the back of the teeth, and the air is expelled at the sides: $\downarrow$ is similar, but more of the tongue is laid against the roof of the mouth, and a greater volume of air allowed to escape. $\tilde{\mathrm{n}}$ is identical with English $n g$ in such words as string.

Words in parentheses in the translations have been added to make the sense of the Indian clearer; bracketed words or parts of words in Indian indicate forms which are inserted in the rhythmic songs, but would be omitted in prose. 


\section{I. - CRADLE-SONGS.}

(Skidegate Dialect.)

Xā'gi lā'nas.

I .

L'djāáada kūdjū's țū Q!ốna l'nagā'-i ya'ksłsī' ga L gaya'oga A woman it was when Skedans the town of middle in its smoke sg̣aqō'nga-łîna's tư $\bar{u}^{\prime}$ hao L djā'adaga-i!

large may be when what (kind of a) woman (are you)!

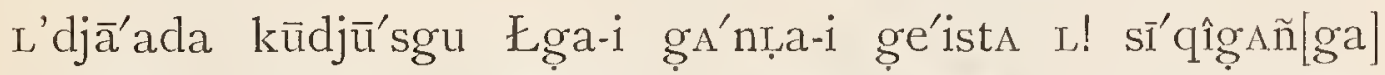
A woman was there Skedans Creek out of they make the noise qa-ix̣una'ñ-tîña's tū'hao L djāadā'ga!

of singing may when what (kind of a)

continually (not) be woman are (you)!

You need not think that the smoke of your house in the middle of Skedans will be as great as when you were a woman (in your previous life upon earth ${ }^{1}$ ).

You need not think that they will make such a continual noise of singing in Skedans Creek as they used to when you were a woman (in your previous existence).

1 The child is considered a re-incarnation of some dead relative.

[5] 
$Q ! \bar{a}^{\prime}$ dasg̣o q $\bar{e}^{\prime}$ gawa-i.

2.

Gî́tîns dja'tgañ ya'+nañ sūgwā't $\bar{n}^{\prime}$.

Eagle woman his own marry he is saying.

Gî́tîns dja'tgañ ya'+nañ sūgwă' $\bar{a}^{\prime}+\tilde{n}$.

Eagle woman his own marry he is saying.

Adĩ'dax̣ua $x^{\prime}$ 'nhao wa'ga gadjü't wan sū'gAñ,

Here behind us yet his wife sits, he says,

Adī'daxua $x^{\prime}$ nhao wa'ga gadjü'twan sū'gañ.

Here behind us yet his wife sits, he says.

HalA' waga daogî̀'+łgēgo-t.

Come his let us go up and get.

HalA $^{\prime}$ waga daogî́ + łgēgo + .

Come his let us go up and get.

Ha hî'djigana xa'nhao wa'ga gă'djiwan sū'wañ, My own boy yet his (wife) sits there he says,

Adī'dex̣ua xA'nhao wa'ga gadjü't wan sū'gañ.

Here behind us yet hiswife sits he says.

He says ${ }^{1}$ he is going to marry his own Eagle-Woman, He says he is going to marry his own Eagle-Woman.

His wife is sitting right behind (the town), he says;

His wife is sitting right behind (the town), he says.

Come, let us go up and get her!

Come, let us go up and get her!

My own boy is saying his wife sits there.

His wife is sitting right behind (the town), he says.

3 .

$$
\begin{aligned}
& \mathrm{Ha}^{\prime} \mathrm{la}+\mathrm{di}^{\prime}+\mathrm{ga}+\mathrm{skîi}^{\prime} \text { nxaLga'go. } \\
& \text { Come for me all wake up. }
\end{aligned}
$$

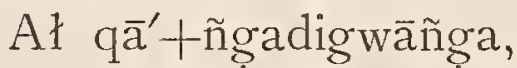

$$
\begin{aligned}
& \text { I dreamed about, } \\
& \text { Ha ha gasîn } n \text { xega'ntîñ. }{ }^{2} \\
& \text { (Laughing) they are going to make } \\
& \text { a noise about him. }
\end{aligned}
$$

1 "To say" is used here for "to cry."

2 Each line of this song is repeated. 
Come, wake up, and listen to me!

I dreamed about it.

$\mathrm{Ha}$, ha! oh, what a noise they are going to make over him (at the potlatch)!

\section{Q $\bar{a}^{\prime}$ gials qe' $\bar{e}^{\prime}$ gawa-i.}

[The following cradle-songs for boys and girls are said to have been sung in the sequence here given when sung at potlatches; at least, the position of the last one was fixed.]

(For Boys).

4.

$\overline{\mathrm{A}}^{\prime}+$ yaña $+\bar{a}^{\prime}+$ yaña $+\overline{\mathrm{a}}^{\prime}+$ yaña $+\overline{\mathrm{a}}^{\prime}+$ yañe $\mathrm{a}^{\prime}+$ yaño,

Be careful, be careful, be careful, be carcful, be carcful,

A +îldja'o-gaña a+îldja'o-gaña a $\bar{a}^{\prime}$ yañē $\bar{a}^{\prime}$ yañē.

One who is a noble- one who is a noble- be careful, be careful. man, man,

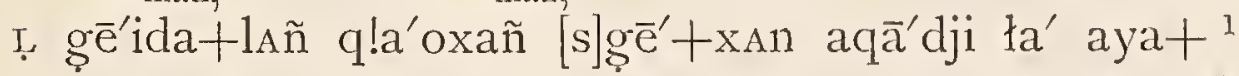
wherever you sit into that place his head here you $(p l$.

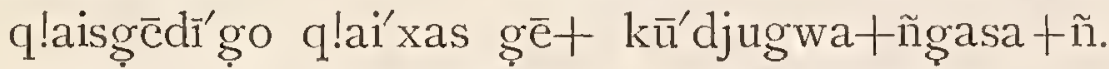
take off and put without anything he will rove about. away

Ayañă'+a îldja'o-ga'ñañ gan dAñ hī'dja gadjū'gAnē.

Be careful one who is a nolle- for you sit as a boy belonging man to a good family.

Be careful of him, be careful of him, be careful of him, be careful of him, be careful of him.

This nobleman, this nobleman, be careful of him, be careful of him,

Wherever you sit, take off his head and put it away, or he will travel about without anything (i. e., in poverty). ${ }^{2}$ Be careful of this nobleman, etc.

1 Aya is equivalent to wa.

2 The father of an Eagle girl must give away blankets to this boy's parents, so that he will marry no one else when he grows up. That is what "taking off his head" means. The reference to his poverty is made with mock humility. 
5.

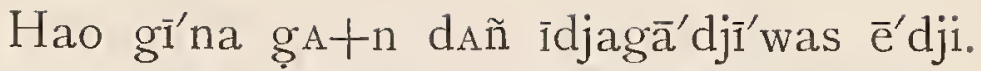

This thing for you sitting as a boy are.

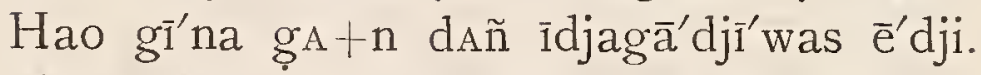

This thing for you sitting as a boy are.

NAñkîllstas $\operatorname{agA}^{\prime} \tilde{n}$ îndalxagā'ganî.

NAñlkîlsLas himself made a human being.

Skîls nagă'ga kūskîndias édji, wA'sta Q!aku'ngwi

Property in the house was, from it Rose Spit towards gàa-iłgaga' ñ dA'ñał Ldjūdal.

his flood with tidal wave went.

Gwa-isku'n xă'-idaga-i xA'nhao dañ nā'ga łkiä'sig̣ei

North Island people even your house towards the door gut gunL!ga'ndias édjî.

are as many as when waves meet each

other and are packed close together.

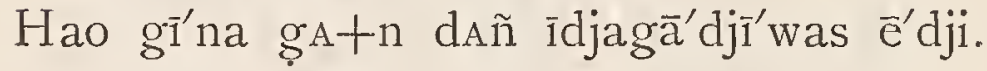

This thing for you sitting as a boy are.

This is why you are a boy

This is why you are a boy

Nañkîllsuas has become a human being.

From the property in his house a flood went towards Rose Spit.

Even from North Island the people are crowded into your house, as when waves meet and are packed together. That is why you are a boy. ${ }^{1}$

6.

$$
\begin{aligned}
& \text { A+ya+ña' }+ \text { ayã ñne } \bar{a}^{\prime}+\text { yañō. } \\
& \text { Be careful, be careful, be careful. } \\
& \text { La hao îldja'oga }+ \text { n. } \\
& \text { He is a nobleman. }
\end{aligned}
$$

1 The child is born to give these great potlatches. His property is likened to the flood raised in the time of NAñkî́lstas, and it is said that people will crowd into his house even from North Island. 
$I^{\prime}+$ lgiañ waga $\tilde{n}\left(\right.$ añ) k $\bar{u}^{\prime}+$ skî̀ + -twas sē+ tụ tcī'nañ qōniga'-i $\begin{array}{ccc}\text { (Face) like it will be whercver your } & \text { his } 5 \text { pland- powerful } \\ \text { changed } & & \text { father }\end{array}$

gì a la qeałdít+ga.

for he looks expectantly.

Ayā̄ñō a o îldja'ogat-n.

Be careful, this is a noblcman.

Be careful (of the child), be careful, be careful.

This is going to be a great man.

His face will be changed wherever he may be, when he looks for the coming of his powerful grandfather ${ }^{1}$ (and sees him).

Be careful, this is going to be a great man.

7.

A +yañe $\bar{e}^{\prime}+\bar{a}^{\prime}$ da gua e $\bar{e}^{\prime} \mathrm{dji}$ tcī'na-i.

Be carcful you ? is grandfathcr.

$A+y a n \bar{e}^{\prime}+\bar{a}^{\prime} d \bar{a}$ gua é $\bar{e}^{\prime}$ jji NAñkî́lsuas.

Bc careful you ? is NAñkî'lstas.

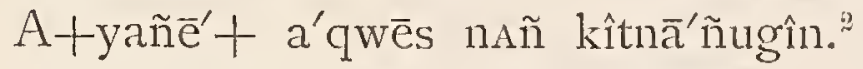

Be careful this sky onc touched.

Be careful. Is this you, grandfather? ${ }^{3}$

Be careful. Is this you, Nañkîlssas?"

Take care. This is perhaps the one that touched the sky."

8.

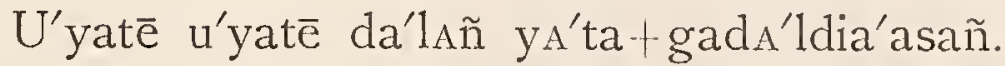

Only only you are going to be a $\mathrm{ys}^{\prime}$ ta. ${ }^{4}$

U'yatē u'yatē da'1Añ y $\Lambda^{\prime}$ ta + gada'ldia'asañ.

Only only you are going to be a $\mathrm{yA}^{\prime}$ ta.

1 Skedans and his peoplc called Djëbasa, the T'simshian chief at Kitkatla, "grandfather," and vice versa. After hc has become a man, the child's face will look joyous when he secs his Tsimshian fricnds approach.

2 Equivalent to ugA'ñgîn.

3 The mother refers to ancestors, onc of whom is possibly bcing reborn in her child. "The one that touched the sky" is Many-Lcdges (T!čs qoa'naiya), a cliff back of Skedans inhabited by a supcrnatural bcing.

4 One of high farnily, who wants for nothing. 


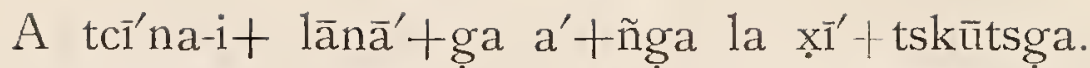

His grandfather's town his he will fill with property seaward.

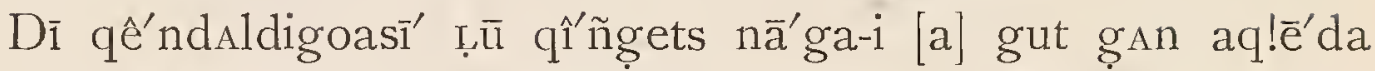
You are of the great since chief's house each (ncar) carving people

qînskitsgā'dias.

large toward the east

(or seaward).

Dala' $\tilde{n}$ yA'ta gada'ldiasañ.

You a $\mathrm{yA}^{\prime}$ ta are going to be.

Only you are going to be a yA'ta.

Only you are going to be a $\mathrm{yA}^{\prime}$ ta.

You will fill up your grandfather's town seaward with property.

Since you are of the great people, your chief's houses will have large carvings seaward.

You are going to be a yA'ta.

9.

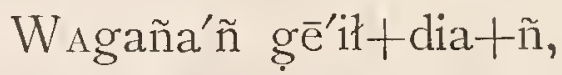

Like it it has become,

W Agaña' ñ $g^{\prime} \bar{e}^{\prime} i ł+d i a+\tilde{n}$, Like it it has becomc,

Gadō'+ Gałga'łda-kun gadō' daLgî́sudiañ.

Around Gałga'tda point around lots of canoes are

WAgaña' $\tilde{n}$ ge $e^{\prime}$ ił + dia $+\tilde{n}$, coming.

Like it it has become,

W'Agaña' ñ ge $\bar{e}^{\prime} i \nmid+d i a+\tilde{n}$.

Like it it has become.

Now it has come to pass,

Now it has come to pass.

Plenty of canoes are coming around Point Gałg ${ }^{\prime}{ }^{\prime}{ }^{2}{ }^{1}{ }^{1}$ (to potlatches).

Now it has come to pass,

Now it has come to pass.

1 A point of land southwest of Skedans village. 
10

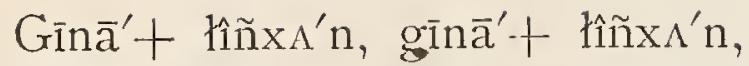
Things all sorts of, things all sorts of, A L nao da'o-gadAldia'ñ, a L nao dao-gadA'ldiañ. As many as grow up well, as many as grow up well. Sqa'gĩ tī'ga q!alı'lî̀nsgua, Dog- kill he is not going to salmon be able,

A L nao dao-gadA'ldiañ, a L nao dao-gadı'ldiañ. As many as grow up well, as many as grow up well.

A xā'gu tī'ga q!alałî̀nsgua a, Halibut kill he is not going to be able,

A L nao dao-gadA'ldiañ, a l nao dao-gadı́ldiañ. As many as grow up well, as many as grow up well. Ga'-igîts tī'ga q!alatî̀nsgua, Cedar-bark kill he is not going (i. e., to ehop) to be able,

A L nao dao-gada'ldiañ, a e nao dao-gada'ldiañ. As many as grow up well, as many as grow up well.

As many things as grow (he may not kill). As many things as grow (he may not kill). Dog salmon he may not kill. ${ }^{1}$ As many as grow, as many as grow. . Halibut he may not kill. As many as grow, as many as grow. Cedar-bark he may not kill ${ }^{1}$ (i.e., chop), As many as grow, as many as grow.

I I .

Gūs łîñ kūdjū'diañ, gūs łîñ kūdjū'diañ? What are you for, what are you for? Sgā'na łî́ñga-i kūdjū'diañ Supernatu- you are (you) are there ral power going to have for Gūs łîñ kūdjū'diañ, gūs łîñ kūdjū'diañ? What are you for, what are you for?

1 Because the slaves will do it for him. 
Gatxała'ñ Lu î́sdala-i kî́lskūna

In front of canoe to (have) he will not him

$\overline{\mathrm{A}}$ 'hao łîn kūdjū'diañ

For that he is going to be

Gūs łîñ kūdjū'diañ, gūs łîñ kūidjü'diañ?

What are you for, what are you for?

Sgăàna łî̀nga-i kūdjūiódiañ.

Supernatu- you are (you) are there

ral power going to have for.

What are you for, what are you for?

You are to have a supernatural helper.

What are you for, what are you for?

You will not let canoes pass in front of you. ${ }^{1}$

That is what you are for.

What are you for, what are you for?

You are to have a supernatural helper.

I 2 .

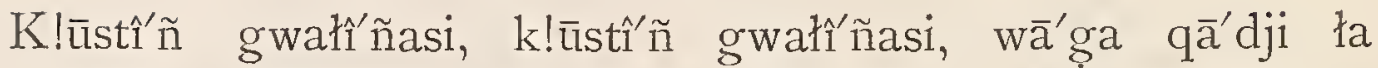
Two if there were, two if there were, their heads I dagaga'ołîñasi.

would keep.

K!ūstî̀ñ gwałî̀nasi, k!ūstî̀ñ gwałîñasi, wä'ga qa $\bar{a}^{\prime}$ dji ła Two if there were, two if there were, their heads I dagaga'ołî́nasi. would keep.

If there were two (boys), if there were two, I would keep their heads.

If there were two (boys), if there were two, I would keep their heads. ${ }^{2}$

1 If people of low family passed close in front of chiefs' houses in their canoes, they might be injured or enslaved.

2 As a mother received property from the parents of the girl her son married, she would have received more if she had had two sons. Mothers who did not make these gifts were laughed at. 
(For Girls.)

I 3 .

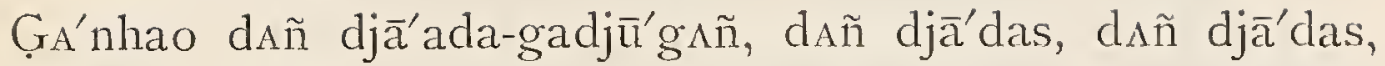
For you are a woman, you are a woman, you are a woman, dAñ djä’adas, dañ djā'adas.

you are a woman, you are a.woman.

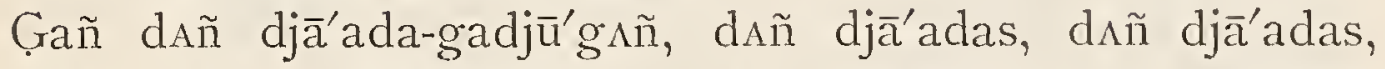
For you are a woman, you area woman, you area woman, dan djā'adas, dañ djä'adas.

you are a woman, you are a woman.

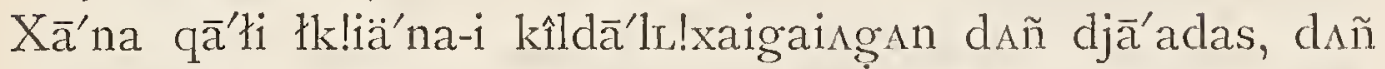

Skidegate Inlet the woods you are going to command you are a woman, you djä́a das.

are a woman.

For this you are a woman, you are a woman, you are a woman, you are a woman, you are a woman.

For this you are a woman, you are a woman, you are a woman, you are a woman, you are a woman,

To command the sticks (i.e., house-poles) of Skidegate Inlet, ${ }^{1}$ you are a woman, you are a woman.

I 4 .

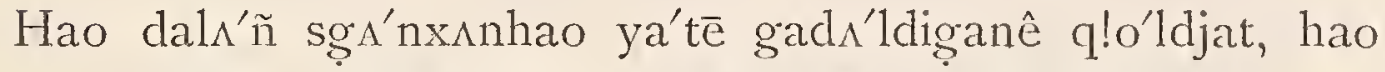
You only ones were brought up ivell chief women,

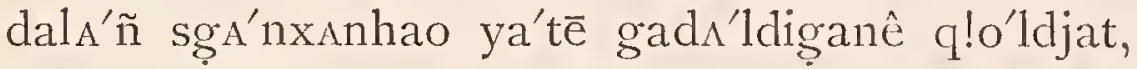
you only ones were brought up well chief women,

Q!ō'na-kun gadō' ga İnda'lu!xaga-iyu.

Skedans point around sit in his canoe and come with him.

Hao dalA'ñ sga'nxanhao, etc. (four times). You only ones, etc.

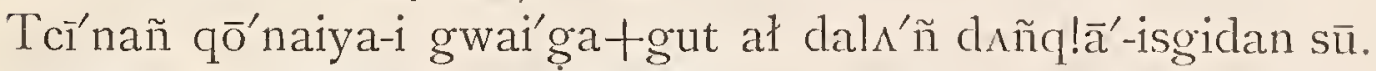

Your grand- powerful hisislands together you pulled it is father

A'ñga gī A'ñgaxawā'yu.

Theirs to how they act with it.

1 The girls of this family often married Skidegate chiefs. So the girl will command when house-poles are to be raised. 
Hao dalA' $\tilde{n}$ sga'nxanhao, etc. (four times)

$$
\text { You only ones, etc. }
$$

Q!êdas k! lia'oga gi gaxa-ūxansLiya'-i yu. ${ }^{1}$

Tattoo for sit down (or take the position).

You, chief women, are the only ones brought up well enough; you, chief women, are the only ones brought up well enough,

To sit in (the chief's) canoe and come around Skedans point with him.

You, chief women, are the only ones, etc. (four times), To pull your powerful grandfather's islands ${ }^{2}$ together, they say.

You, chief women, are the only ones, etc. (four times), To sit down to receive tattoo-marks.

I 5 .

Hao a'+gadal, hao a'+gadal, a tcī'na nā'ga qā'łi + gut That is right, that is right, grandfather's house inside around

dao ${ }^{3}$ gutils q!a-iguxanskiä'nsi. in different sit around in groups parts (the slaves).

WA łkia'gua gaga'-i nañ q!a'ouwas la hao aga' ñ gā'djida Near the door far off one sits him let take care of you hao $\operatorname{ags}^{\prime} \widetilde{n}$ gada'lda

let him take care of you

Hao $a^{\prime}+$ gadal (eight times).

That is right.

That is right, that is right, (the slaves) sit in groups around the inside of your grandfather's house.

Let the one sitting far off near the door take care of you, take care of you.

That is right, that is right, that is right, that is right, that is right, that is right, that is right.

$1 \mathrm{Yu}$ is equivalent to hao.

2 "Your grandfather" is Raven, and the islands are the Haida country and the mainland. Reference is perhaps made to mainland marriages.

3 Equivalent to ga-i. 
I 6.

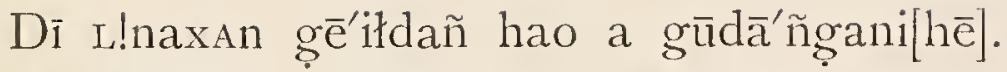

I like that becamc they used to wish.

Wagaña' $\tilde{n}$ o la gēiłsgia'ñ hao $\bar{o}$.

Like that

she becamc soon.

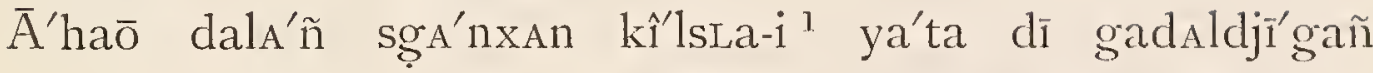
You only chief only you are (said of a high (or fit) family)

hao $\bar{o}+$.

They used to wish that I should be like that.

Like it she soon became.

You are the only ones fit to be chiefs' daughters.

I 7 .

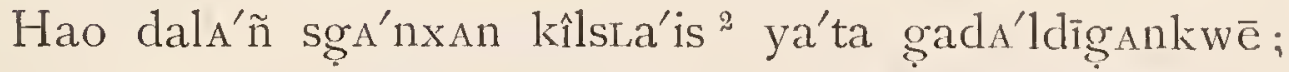
You only chicf are of a high family;

Hao dala' ñ sga'nxan kîlsLa'is ya'ta gada'ldighankwe.
You
chief
are of a high family.

Gī L! (aya+) q!otgăāñdixan djā'gada'ñganî.

For they used to be soliciting (they) tried to get the woman a long time.

Hao dala'ñ sg̣a'nxan kîlsta'is ya'ta gada'ldīgsnkwē;
You
only
chief
are of a high family;

Hao dalA'ñ sg̣a'nxan kîlsua'is ya'ta gada'ldịgankwē.

You only chief are of a high family.

You alone are fit to be a chief woman,

You alone are fit to be a chief woman.

For (you) they begged a long time (to obtain you in marriage).

You alone are fit to be a chief woman,

You alone are fit to be a chief woman.

1 Or gī'tsîs ("chief's daughter").

2 The second verse of this song is identical with this onc, except that q!o'ldjat ("chief woman") is substituted for lî̂lsLa'is whercver it occurs. 
I 8.

Hals' ga'gîn gao-o (eight times)

Come, let her sit on my lap

(or "let us have her")

Ga ga'os wațū'xan ła gu'tgi gagaga'ñgao gu'tgī ska'nThe villages all to each other hand (her) to each other hand. dịgo ła.

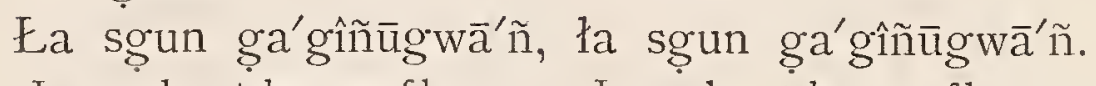

I only take care of her now, I only take eare of hcr now. $\mathrm{HalA}_{\mathrm{A}}^{\prime}$ ga'gîñ gao-o (several times).

Come, let her sit on my lap.

Come, let her sit on my lap! (eight times)

All the villages used to hand her to one another.

Now only I take care of her, now only I take care of her. ${ }^{1}$ Come, let her sit on my lap! (several times)

I 9.

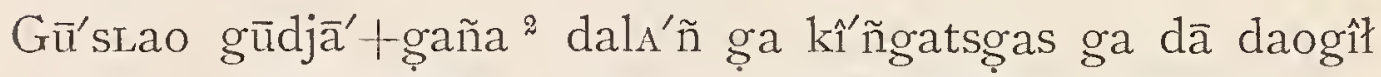
Why your daughters you to news went down what did you gadā'lañ?

well bronght up one?

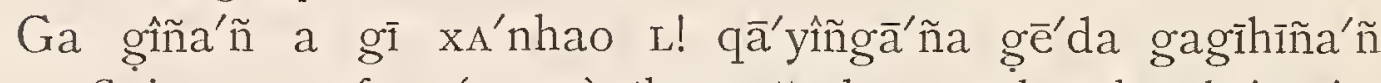
Crying for (no one) they attend you plaee where she is crying gaga'ogwañ gadıl, g̣éc'da gagīhĩñañ gaga'ogwañ gadAl. lying about, well brought place where she is erying lying abont, well brought up one, up one.

On account of what news of your daughters ${ }^{2}$ going down to you (to The Land of Souls) did you come up for something, well brought up ones?

There is now no one to attend to you on account of your crying, where you are crying about (because there are now no slaves), well brought up one, where you are crying about, well brought up one.

1 This means that all the people of all villages used to be slaves of this family, and so took care of the baby, but now the mother has to do it all herself.

2 The second verse of this song is identical with this one, except that $\overline{\text { ugo }} \overline{0}^{\prime} \tilde{n}$ gaña ("your fathers") is said to be substituted for the words gn̄jja't + gaña ("your daughters"), but goo'ñga is properly applied only to a man's father. 
20.

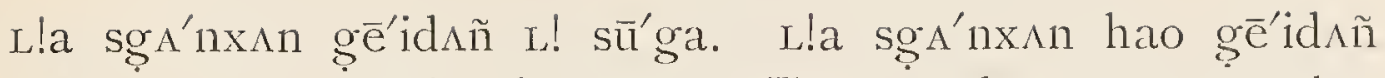
Those only are that they say. Those only are that

L! sū'ga.

they say.

Gam il! ca geitgā'ñañ L! sū'ga.

Not (with) how- it was that they say.

us ever. way

They alone belong to a high family, thcy say. They alone belong to a high family, they saly.

But it is not that way with us, they say.

$2 I^{1}$

Ha LA ha $\mathrm{La}+$ ha $\mathrm{Le}^{\prime}+$, ha $\mathrm{LA}$ ha $\mathrm{La}+$ ha $\mathrm{Le}^{\prime}+$. (Langhter)

$\bar{A}^{\prime}$ ga łgłga'odīgan sgoa'na gwē+,

Here is biack ground used one [of thcm],

where to be

Ha la ha $\mathrm{La}+$ ha $\mathrm{Le}^{\prime}+$, ha $\mathrm{LA}$ ha $\mathrm{La}+$ ha $\mathrm{Le}^{\prime}+$.

(Laughter)

A gă'ldjidas ${ }^{2}$ gā'ñañ, a gă'ldjidas gă'ñañ.

Crow like a, crow like a.

Ha la ha lat ha $\mathrm{Le}^{\prime}+$, ha la hà Lat ha $\mathrm{Le}^{\prime}+$.

Here is where one of the black tattoo-marks used to be, Ha LA ha La+ ha $\mathrm{Le}^{\prime}+$, ha LA ha La+ ha $\mathrm{Le}^{\prime}+$. (Black) just like a crow, (black), just like a crow.

This song has to be sung last.

2 The baby word for "crow."

3 Probably this refers to the place where the child is supposcd to have been tattooed in her former existence on earth.

2-PUBL. AMER. ETHN. SOC. VOL, III. 


\section{Q!ō'na qe'gawa-i.}

\section{2.}

Hao tcī'nAñ lanā'g̣a gua dā dā'ga.

Your grandfather's town ? you own.

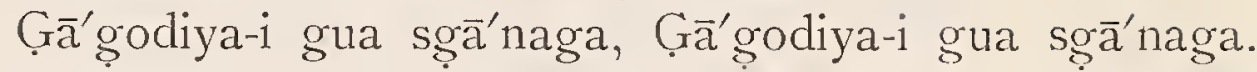

Lies large ? is it powerful, Lies large? is it powerful.

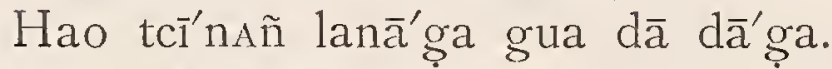

Your grandfather's town ? you own.

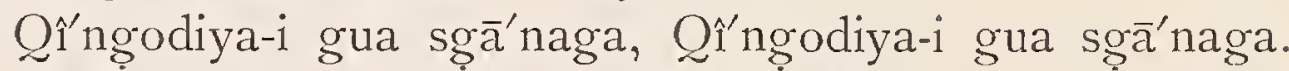

Lics down greatly ? is it powerful, Lies down greatly ? is it powerful.

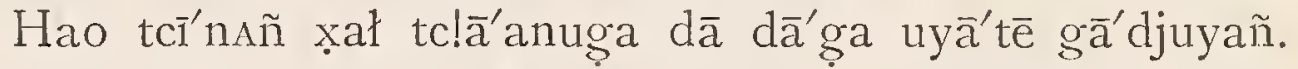

Your grand- copper fire you own you only to sit greatly. father's are fit

Do you own your grandfather's town?

Lying large, has it supernatural power? Lying large, has it supernatural power?

Do you own your grandfather's town?

Lying greatly, has it supernatural power? Lying greatly, has it supernatural power?

You only are fit, sitting greatly, to own your grandfather's copper-fire.

\section{(In Tsimshian.)}

$$
23 .^{1}
$$

$\mathrm{No}^{\prime}+$ gunatō' + na + gunatō' + (six times)

Wa+ gîtcī ${ }^{2}$ q!ayam gwa'taksta nałnīgan ahō'yūda down river (?) near cry (?)

wâlsî́mgīgyêt ${ }^{3}$ damgī + ${ }^{4}$ q!ado ${ }^{\prime}+$ noble men

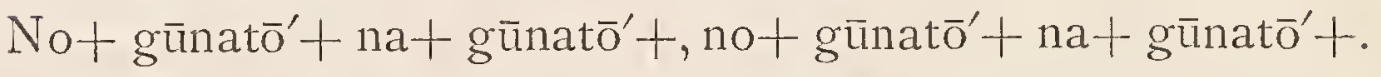

1 This and the following song are unintelligible, although a number of words may be recognized.

2 Perhaps gîsi ("down river").

3 The translation of this word applies only to the lattcr part of the word, excluding the first three letters.

4 DAm indicates future. 
(In Tsimshian.)

24 .

Hēe-è-ē-ēe gwấldıma aga'-i (six times)

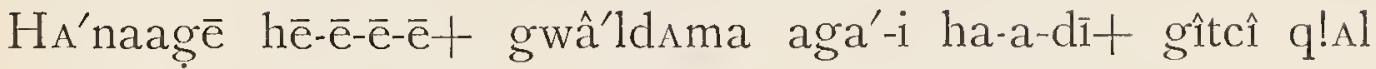
Woman

mâs (a) nī'cīna ałg $\bar{u}^{\prime 1}$ ha-a-dī + gił bêlha ałgu not (?)

Hēè-ēe-è+ gwâ'ldama aga'-i (three times).

Egạai- $\bar{u}^{\prime} l \bar{a}^{\prime}$ nas.

25.

Dīnnañ djat $\tilde{i}^{\prime}+$ ngadju+

My child a (comes out having) woman married,

DínAñ djat $\bar{i}^{\prime}+$ ngadju+

My child a (comes out having)

[Aq!a] Q!aiya'-i aq!ōłg $\bar{u}^{\prime}$ stAt, $^{\prime}$ Q!aiya'-i from the top of,

Dī'nÃ̃ djat $\bar{i}^{\prime}+$ ngadju+

My child a (comes out having)

Dī'nañ djat $\bar{i}^{\prime}+$ ngadju + .

My child a (comes out having)

My child comes out married,

My child comes out married,

From the top of (Mount) Q!aiya'-i,

My child comes out married,

My child comes out married.

1 Probably a'łge ("not"), or tgu ("small"). 
26.

Gît'î́n-djatsgañ yā'nañ + s $\bar{u}^{\prime}++g a \tilde{n}$;

Eagle-woman his has already he is saying;

own married,

Gît'î'n-djatsgañ y $\bar{a}^{\prime} n a \tilde{n}++$ sü' +gañ.

Eagle-woman his has already he is saying.

Adī'dnxua xánhao wa'ga gă'djiwañ sū.

Near rightbehind even his sits greatly, he [the town] says.

Ha'lai wā'ga da'ogîłkūxaogō;

Come, his (wife) let us all go up and get;

Ha'lai wā'ga da'ogîłkūxaogō.

Come, his (wife) let us all go up and get.

Adīidaxiua xA'nhao waga gă'djiwañ su.

Near right behind even his sits greatly he

the house says.

$\mathrm{He}$ is saying he has married an Eagle woman;

He is saying he has married an Eagle woman.

He says she sits greatly right behind (the town).

Come, let us all go up and get her!

Come, let us all go up and get her! ${ }^{1}$

He says she sits greatly right behind (the town).

27.

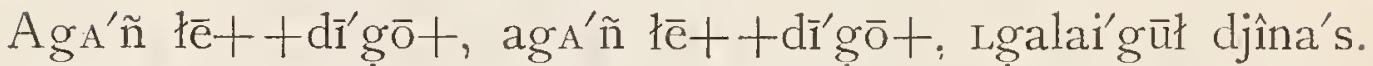
Get ready (for him), get ready (for him), Lgalai'gūł women of.

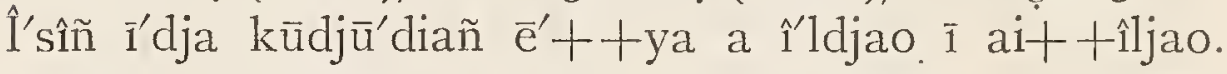

Again it is a boy, here nobleman, nobleman.

Get ready for him, get ready for him, ${ }^{2}$ women of the Lg̣alai'gūł ${ }^{3}$ family. Again it is a boy. ${ }^{4}$

\footnotetext{
1 This refers to the marriage customs.

2 That is, to marry him.

3 An extinct branch of the Gî́tîns of Skidegate.

4 Indieating that boys were searee.
} 


\section{$28 .^{1}$}

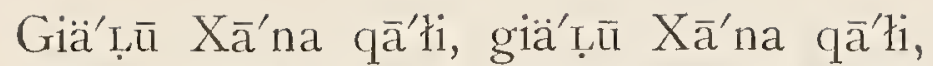
At the Skidegate Inlet, at the Skidegate Inlet, time lime

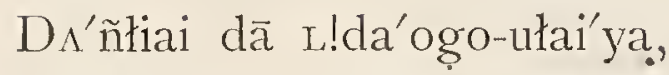

Toswell up you burst (on that day),

Sgałē îstā'ūłi kî́lsta-i (four times).

Secret having chief.

Society one day [or morning],

Ga-i łム îsta-uł kî́lsLa-i (four times).

That doone day chief. (again),

Ga'odjaos ga'-iła îsta-uł kî́lsta-i.

Drum (town) at that do itsome chief.

place day,

Skidegate Inlet, Skidegate Inlet.

When you burst with swelling,

You had the Secret Society perform one day, chief.

Do it again, chief!

Do it one day at Drum Town, chief!?

29.

Dalı'ñ sgu'nxın gua $+\bar{a}^{\prime} h a o$ qîndia'haowus

you only $?$ here look about

Tcínañ łk!ia'nga A'ñga dalı'n hao ha-iludā'le!xa ūya'te Grandfather's timbers yours you got all out of the only fit
(i. e., Raven

(i. e., Raven

peoples')

$\operatorname{gad} \wedge^{\prime}$ ldigwa' ñ.

highly moving around.

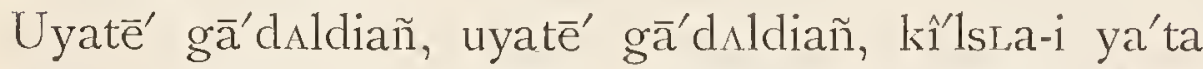

Only fit highly moving only fit highly moving chief fit to be gă'dAldiañ.

highly moving around.

1 The oldest of the set.

2 Onee when there was a great famine in Skidegate Inlet, the ehief of Drum Town had enough property to hold a potlatch and save every one from starvation. 
Are you the only ones who sit looking about?

You are the only ones fit to get all your grandfather's timbers ${ }^{1}$ out of the woods, chiefs highly moving around. Highly moving around, highly moving around, chiefs highly moving around.

$\mathrm{Na} y \bar{u}^{\prime}$ Ans $x \bar{a}^{\prime}$-idag̣a-i.

30.

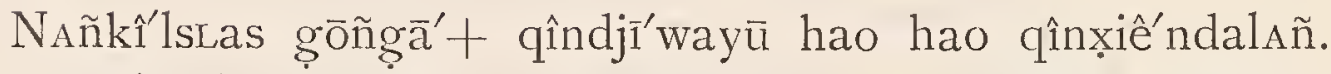
Nıñkî'lsLas's father a great one, such a great one coming along.

Gua + qînge ē'dao î̀-dja'n sū qî́nłgałwañ.

Halloo! great chief is he great one moving

Gua' $^{\prime}$ qwīga (gī) gī'na gagîtłūgîn ü'hao hao îs

Halloo! sky to some- stretched up he is it is he

qînxiềnndal-Añgua'.

thing (like a rope) there,

great one moving along.

Qîñgē'dō ì +dja'n sū qî̀ñ̂łgałwañ gua'.

Great chief is he great moving halloo!

He says it is NAñkî'lsLas's great father moving along so greatly.

Halloo, great chief moving about!

Halloo! he moves along greatly like something extending to the sky.

Halloo great chief moving about! ${ }^{2}$

1 That is, the Raven peoples' house-timbers. The baby is addressed.

2 NAñkî'lstas's father would be an Eagle, and the mother pretends that he is reborn in her child. 
$3 \mathrm{I}$.

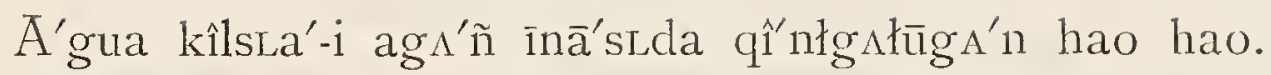
Here is ehief growing himself up so great as he sits.

DAñ kîñ̃gat ugua', dañ kîñngat ugua'.

You are getting rich (or you are getting rieh (or great) sitting there, great) sitting there.

Dañ sLū'łgałwañ gua'. Dañ+ qî́ñ łgałwañ gua'.

You are moving so greatly You are highly moving as as you sit. you sit.

DAñ kîñogat ugua', dañ kî́nggat ugua'.

You are getting rieh (or you are getting rieh (or great) sitting there, great) sitting there.

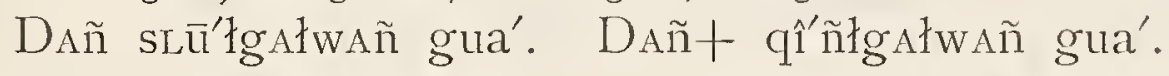

You arc moving so greatly You are highly moving as as you sit. you sit.

Dañ sLī'łgalwañ gua'.

You are moving so greatly as you sit.

Here the chief causes himself to grow up greatly as he sits.

You are becoming great, you are becoming great.

You are moving so greatly as you sit. You are moving highly as you sit.

You are becoming great, you are becoming great.

You are moving so greatly as you sit. You are moving highly as you sit.

You are moving so greatly as you sit.

Eg̣ā'xetgu lā'nas.

32.

[Hao] î́sîn [a a] Lgua' |a] dAñ lalā'ga +gaga [ha] xēga'nłAgain I do not your screcns inside there will be îña'-us wagî̀ $+g \bar{a}^{\prime} g \hat{i}$ ĩna' ñ gā'łgałwan.

a noise for it (you) are (you) are moving crying whilc sitting down. 
I do not expect there will again be a noise inside your screens, for which you sit crying. ${ }^{1}$

33 .

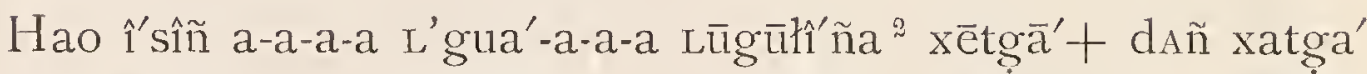
Again perhaps Upsct-Canoc in front of your father

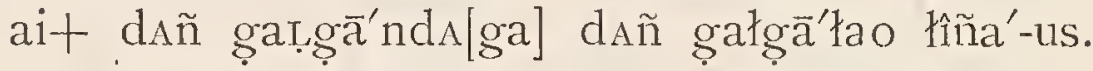
you look around at new you taken care of expect to things sitting be.

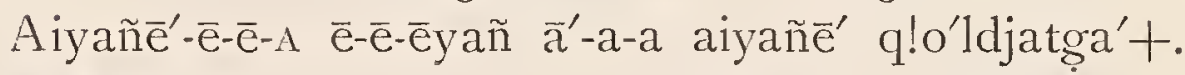
Be careful, be careful, chief-woman.

Hao îsîn a-a-a-a L'gua'-a-a-a giếsta t!ăgo xandja'os gẹe Again perhaps from where copper came from around

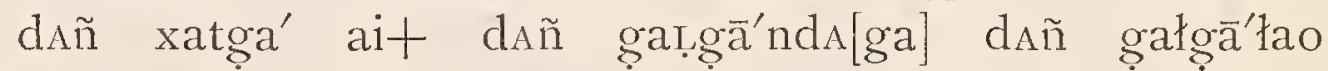
your father you look around at new you be takencarc łîña'-us. things of sitting

expect to be.

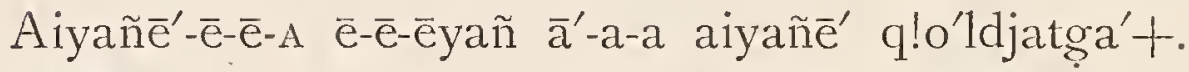
Be careful, be careful, chief-woman.

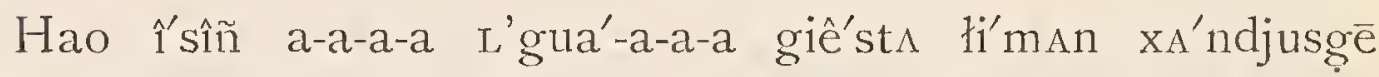
Again perhaps from wherc hide of some came around mainland animal

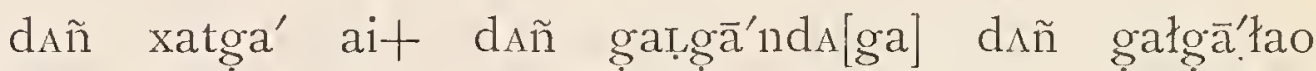
your father you look around at new you be taken care fîña'-us. things of sitting expect to be.

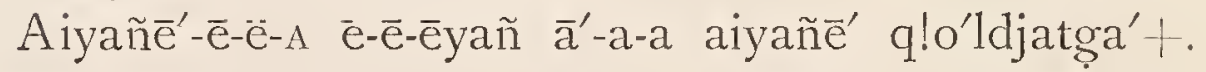
Be careful, be careful, chief-womin.

1 These words are intended as a gentle reproof, reminding the child that he is too high bor'n to cry in that way.

2 A place north of Cape Ball. 
Hao î'sîñ a-a-a-a L'gua'-a-a-a giếsta gu'lxas xa'ndjus gēe Again perhaps from wherc bigvariety came around of abalone

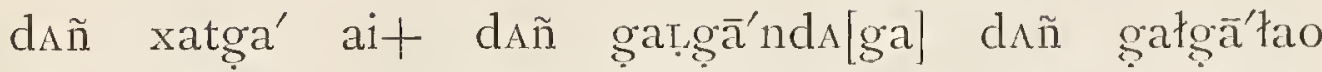
your father you look around at new you be takencare łîna'-us. things of sitting expeet to be.

Aiyañe $\bar{e}^{\prime}-\bar{e}-\bar{e}-\Lambda$ è-ē-êyañ $\bar{a}^{\prime}-a-a$ aiyañe $\bar{e}^{\prime}$ q!o'ldjatga't. Be careful, be carcful, chief-woman.

Again perhaps you expect to sit up high in your father's canoe, ${ }^{1}$ chief-woman, and look around upon all things in front of Upset-Canoe.

Be careful, be careful, chief-woman!

Again perhaps you expect to sit up high in your father's canoe, chief-woman, and look around the place whence coppers come.

Be careful, be careful, chief-woman!

Again perhaps you expect to sit up high in your father's canoe, chief-woman, and look around the place whence ti'man-hides come.

Be careful, be careful, chief-woman!

Again perhaps you expect to sit up high in your father's canoe, chief-woman, and look around the place whence abalones come.

Be careful, be careful, chief-woman.

1 Chiefs' children uscd to be plaecd high up on blankets in the centre of trading-canoes so that they could look about. Here the baby is reminded of what she used to do in a former existence. 
34 .

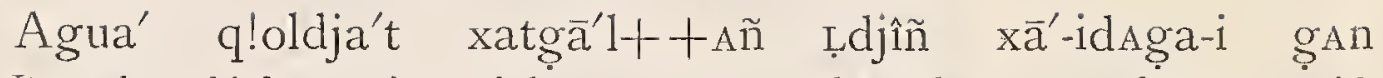
It may be clief-woman's fathers Bella Bella people with LūsqA'sL îndjā'was gu tc!aanū' djīîña lă'na ła'-a-a-a return by from being there the fire next to that let canoe angry

one

agA' ${ }^{\prime} \tilde{n}$ ha-i tclitga $\bar{a}^{\prime} g o$ g $\bar{u}^{\prime} a n d a$.

let watch and tend you while you

lie about.

Gūista gī dā'gāgîña' ñ gałgū’łwañ?

What for are you crying and sitting around

as a noble sits?

Gū'sta gì dā'gāgîña' ñ gałgü'łwan?

What for are you crying and sitting around

as a noble sits?

Agua' q!oldja't xatgăāilt+Añ Gwai'got xă'-idaga-i gan It may be chief-woman's father's

Ninstints people with

LūsqA'sL îndjā'wAS gu Egia'gusta lāna ła'-a-a-a agA'ñ return by from being there (one) next to that let let canoe angry the door one

ha-i tclîtgā'go gō'anda.

watch and tend you while you

lie about.

Gū'sta gī dā'gāgiñna'ñ gałờ'łwañ ?

What for are you crying and sitting around

as a noble sits?

Gū'sta gī dā'gāgîñ̃a'ñ gałg'̄'łwañ?

What for are you crying and sitting around

as a noble sits?

Perhaps when the chief-woman's fathers return from being angry with the Bella Bella people, that one (captured slave) next the fire will take care of you while you are lying about.

For what do you cry as you sit like a noble's child?

Perhaps when the chief-woman's fathers return from being angry with the Ninstints people, that one next to the door will take care of you while you are lying about. For what do you cry as you sit like a noble's child? 
tư $\bar{u}^{\prime}$ gua nAñ na'nga st!a-i dja'kia qîndjă'waxañ : wagi At that some grand- hand woodentray has bcen liurt, for it time one's mother with square sides I hcar:

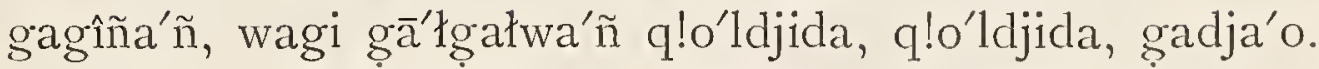
(you) cry, for it (you) sit and ehief-woman ehief-woman, sit and move around (i. e., the body),

Perhaps you are crying and are moving around for your grandmother's hand, which was hurt on a wooden tray, chief-woman, chief-woman.

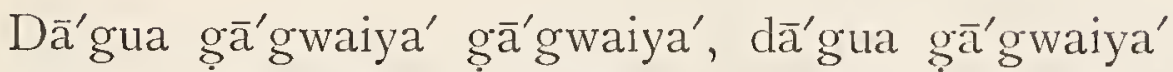
You? (whence) have have been you? (whence) have been falling falling, bcen falling,

gā'gwaiya'.

have been falling.

Dā'gua ga'gwaiya' gă'gwaiya'

You ? have been falling havc been falling

Sq!aos qās gūista gua da gagwaiya' gagwaiya' da Salmon- top of fiom ? you have becn have been you berry bushes falling falling

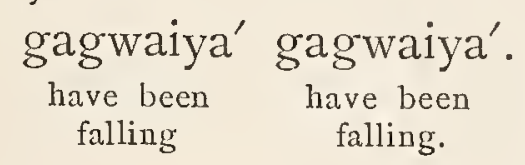

Whence have you fallen, have you fallen? Whence have you fallen, have you fallen?

Did you fall, fall, fall, fall, from the top of the salmonberry bushes?

I A woman of this family had such a large hand, that she eould pick up enough berries to fill a wooden tray. This story is referred to, but the wording is rather obscure.

2 That is, "How did you come to us?" 
37.

Ha-iłä' gīdona'; ' ha-iłä' gīdona'.

Stop crying, chief's child; stop crying, chief's child.

Hao îsî́ñ hî́ñ lgua à gîtsîs gaodjuwa'-i hao dañ gạ Again I do not chief's child's drums you for expcct

xēgîłdia' łîna'gūs. Ha-i wA'gî(ñ) g̣agîna'ñ g̣ałgāłwañ. sound are going to. Now for it crying moving about

Ha-iła' gîth $\bar{u}^{\prime} n a$ gadjū'onan. seatcd.

$\begin{gathered}\text { Stop } \\ \text { crying, } \\ \text { Hai hai great chicf's child of noble } \\ \text { child }\end{gathered}$
family sits.
Now, now, great chief's gan. gald of noble
child

Ha-iłä' gīdona'; ha-iłä' gīdona'.

Stop crying, chief's child; stop crying, clief's child.

Hao îsîñ̃ hî́ñ lgua à gîtsîs gua'gana'-i hao dan gạn Again I do not chief's child's heavy planks you for expect

qî́ñgao dīa'o łîna'gūs. Ha·i wa'gîn $[\tilde{n}]$ gagâñ̃a'n are going to lay are going to. Now for it crying gałgā'łwañ.

inoving about seated.

Ha-iła' gith $\bar{u}^{\prime}$ na gadjü'gan.

Stop great chief's child of moble

crying, child family sits.

Hai hai gîthūna' gadjü'gan.

Now, now, great chief's child of noblc child family sits.

Stop crying, child! Stop crying child!

I do not expect that drums will sound for you, the chief's child, again, for which you are moving about crying.

Stop crying, great chief's child!

Stop crying, great chief's child!

1 Ha-iłä' gìdona' is equivalent to Lä'na gut u'łda nAñgida's. 
Stop crying, child! Stop crying, child!

I do not expect that they are going to lay heavy planks for you, the chief's child, again, for which you are moving about crying.

Stop crying, great chief's child!

Stop crying, great chief's child! ${ }^{7}$

$$
38 .
$$

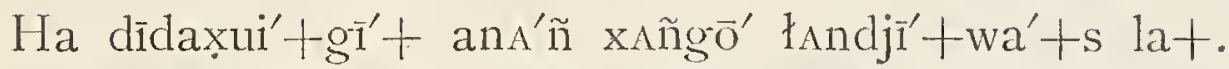
Towards the woods some one facing sitting down (like le (who common people) was sitting).

Dja Lana' q!o'guga $+\bar{o}+$.

Say, stop telling lies.

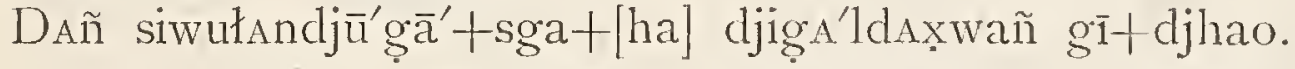

Your month will be crooked mosquito (i. e.,
common people)

One sits here like a common person facing the woods. Say, stop telling lies!

Your mouth will become crooked, mosquito people.2

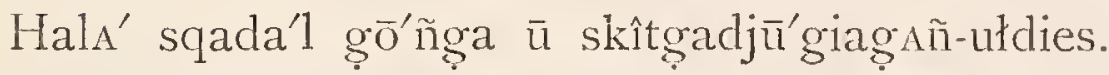
Come, chief's child's father, sing a song for the child this (accompanied by drumming) morning.

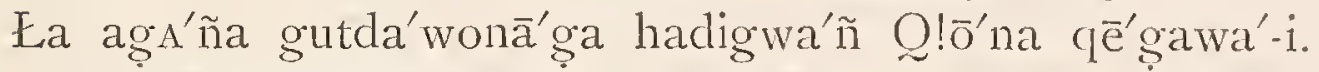
You yoursclves make ready in mind and time Those-born-al-Skedans.

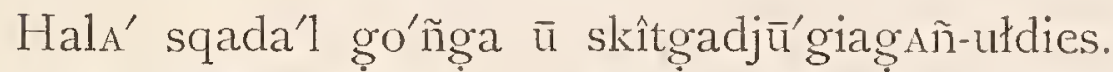
Come, chief's child's father, sing a song for the child this (accompanied by drnmming) morning.

Ea agA'ña gutda'wonā'ga hadigwa' ñ Djî́gua ał lā'nas.

You yourselves make ready in mind any time Town-of-DjI'gua-People.

1 All this refers to potlatching and house-building.

2 Some onc uses the low-class word for "sitting down" to the child, and is told to stop or the wealthy will give away so many blankets as to put him to shame and "give him a bad name." That is what is meant by "your mouth will become crooked." Common pcople arc called "mosquito people." 
HalA' sqada'1 gơóñga ù skîtgạajūúgiag̣añ-ułdies.

Come, chief's child's father, sing a song for the child this (accompanied by drumming) morning.

Ea ag̣a'ña gutda'wonā'g̣a hadigwa'ñ Dă'gañ sêl gĩda'-i.

You yourselves make ready in mind any time Common-Food-Steamers.

Come, chief's child's father, sing a song for him, accompanied by drumming, this morning!

Be ready, Those-born-at-Skedans!

Come, chief's child's father, sing a song for him, accompanied by drumming, this morning!

Be ready, Town-of-Djí' ${ }^{\prime}$ gua-People!

Come, chief's child's father, sing a song for him, accompanied by drumming, this morning!

Be ready, Common-Food-Steamers ! ${ }^{1}$

40.

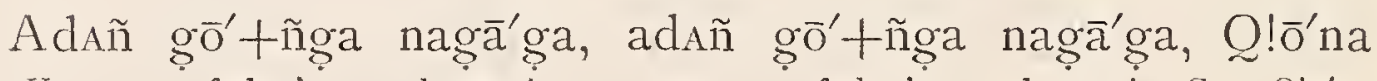
Your father's house in, your father's house in, Cape $2 ! o^{\prime} n a$ kun sq!ếna-i hao[a] ga ta goñałxa'ndies. sea-gulls eating things are making cries.

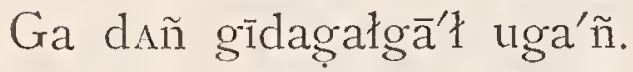

All you are going to proudly these move as you sit.

things

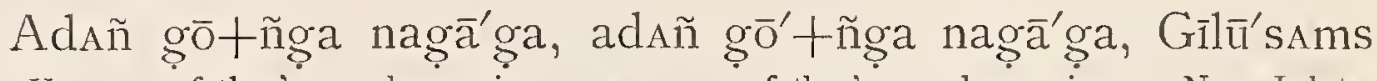
Your father's house in, your father's house in, Nass Inlet sq!è'na-i hao[a] ga tā goñałxa'ndies.
sea-gulls
cat things are making cries.

Ga dÃ̃ gìdagałgałáł uga'ñ.

All you are going to proudly

these move as you sit.

things

1 The families are told to be on the alert for invitations to a potlatch, when the child will be tattooed, etc. 
In your father's house, in your father's house, Cape Q!o'na sea-gulls ${ }^{1}$ make cries as they eat.

You are going to bear yourself proudly in the midst of these things.

In your father's house, in your father's house, Nass Inlet sea-gulls make cries as they eat.

You are going to bear yourself proudly in the midst of these things.

$$
4 \mathrm{I} \text {. }
$$

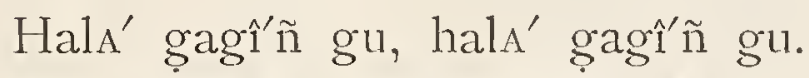

Come, let us take there; come, let us take there.

(the baby) on

(the haby) on

our knees

Gōonga na'g̣a qā'łi gutgī gagaga'̃̃, gutgī gagaga'ĩ.

Its father's house insicle to eaeh liand it, to eneh hand it.

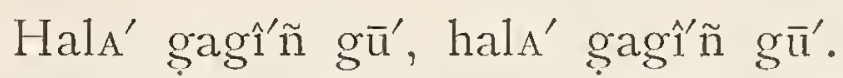

Come, let us take it eome, let us take it on our knees, on our knees.

Come, let us take (the baby) on our knees! Come, let us take (the baby) on our knees!

Hand it to one another inside of its father's house, hand it to one another!

Come, let us take it on our knees! Come, let us take it on our knees!

42.

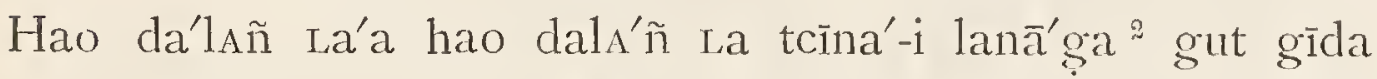
You you grand- town "pon ehiefs' ganłgałdiā'n, father's children walking about,

1 That is, those invited to the potlateh.

2 Sometimes qaqa'nga ("his town"), perhaps qaga'oga, was substituted for lanā'ga. 
Dala'n sgun ya'dañs gî́tsîs, dalA'ñ ya'daga.

You (are only fit to be chiefs' you are fit to be. the) (ones) children,

Sqada'1s dala'ñ ya'daga,

Great ones you are fit to be,

Gîtsî́s dala'ñ ya'daga.

Chiefs' you are fit to be.

children

You walk about as chiefs' children in your grandfather's town.

Only you are fit to be chiefs' children.

You are fit to be sqada'1 (close relatives of chiefs).

You are fit to be chiefs' children.

Stasa'os qe' gawa-i.

43.

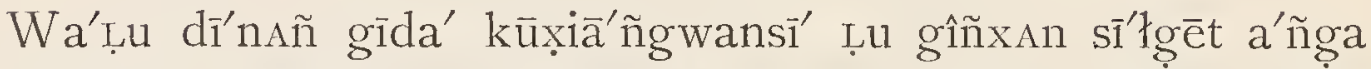
At that my child youth goes around as a when for alone, my own
time

ła q!ā'-ugwañ.

I sit around.

When my child becomes a youth, I shall vainly sit around alone (for he will go to live with his uncle).

44.

Gî̀tîn-dja'tgañ ianā't $+\tilde{n}$ sự'wañ.

Fagle woman of he married he says.

Adī'daxua xA'nhao waga gă'djiwañ sū'ugañ.

Here behind us yet his (wife) is sitting, he says.

Adĩ'dax̧ua xa'nhao waga gă'djiwañ sū'ugañ.

Here behind us yet his(wife) is silting, he says.

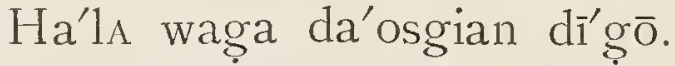

Come, his (wife) let us all go and get! 
$\mathrm{Ha}^{\prime}$ lA waga da'osgian dígo.

Come, his (wife) let us all go and get!

Adìdax̣ua xa'nhao waga gắdjiwan sü'ugañ.

Here behind us yet his (wife) is sitting, he says.

Ha'la waga da'osgian dì'go.

Come, his(wife) let us all go and get!

He says he has married his own Eagle woman.

Here behind us he says his wife is sitting.

Here behind us he says his wife is sitting.

Come, let us go and get her!

Come, let us go and get her!

Here behind us he says his wife is sitting.

Come, let us go and get her!

45.

DAñ sg̣u'nxa'n gua djāáada kudjū'diawîs, You are not the woman we who belong to only one a low family,

DAñ sgu'nxa'n gua djā'ada kudjū'diawîs.

You are not the woman we who belong to only one a low family.

Djia'djats hao qoa'nga, Women arc plenty,

Djia'djats hao qoan kuha'oga.

Women plenty belonging to a low class.

You are not the only woman of our low-class family, You are not the only woman of our low-class family. There are plenty of women, There are plenty of low-class women. ${ }^{1}$

1 This contains a polite self-abascment, which is of course intended to be taken in exactly the opposite sense.

3-PUBL. AMER. ETHN. SOC. VOL. III. 
Sqoāładas.

46.

WA'ga xếgañ qeñgî́ndala-i (four times).

His(son or making a great went by on daughter) noise the water.

Agua ga'-idjixuihao.

I wonder which way he is going

(i. e., the child)!

WA'ga xế'gAñ qeñgî́ndala-i.

His (son or making a great went by on

daughter) noise the water.

A'gua gwaisku'ngwi.

It must towards the north

be point of the islands.

His great son (the child) went by upon the water with a great noise.

I wonder whither he is going!

His great son went by upon the water with a great noise. Perhaps to North Island (to invite the people to a potlatch).

47.

Hĩ hīyaihīya gwa-i kî́lsıa-i hao ahai'ya aya q!ai'gîndalAñ Island chief this was coming

1 gūdA' $\tilde{n}$ hao $\overline{1} h \overline{1} \bar{i} h \overline{1}$ ahaiya

I thought, but

Kîlsca'-is Lua'-i Lla qêngîndala-i, hī hīyai hĩya.

Chief's canoe, however, comes greatly.

I thought the island chief ${ }^{1}$ was coming, But the chief's canoe comes greatly. ${ }^{2}$

1 The "island chief" probably refers to Raven or another supernatural being.

2 That is the canoe of this infant. 
48.

Ayā̄ña kî́lsca-i gā'ña (four times).

Be eareful of chief my own.

Dja Lan ła q!ó'gugago.

Say, stop biting.

DAñ si- $\bar{u}^{\prime}$ djigu'ldaxwañ gī̄la'-i.

Your month mosquitoes common might be- things.

come crooked

Be careful of my chief.

Stop biting!

Your mouth might become crooked, common mosquitoes. ${ }^{1}$

49.

Dā gut gua gagorwai'ya gagorwai'ya; qa'-idjis qās gū'st

You your ? to fall into to fall into sprncc top from mind (the cradlc) (the eradle);

made up

gagwai'ya; sq!aos qās gū'sta g̣agwai'ya.

to fall in; $\begin{gathered}\text { salmon- } \\ \text { berry bush }\end{gathered}$ fop from to fall in.

Did you make up your mind to fall (into the cradle), to fall in from the top of a spruce-tree, to fall in from the top of a salmon-berry bush?

50.

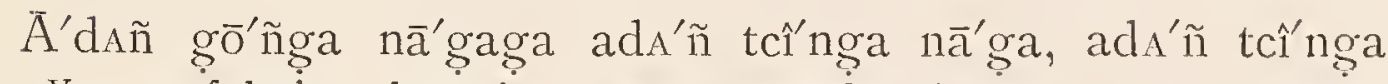
Your father's house in, your grand- house, your grandnā'gạ, house,

Gilü'sams ${ }^{2}$ sq!ēéna-i ga tagōóñałxandies ga dã̃ qoya' Nass Inlet sea-gulls make a noise while eating in you dear gà'łgałwañ.

move about highly.

1 The singer is probably drawing an analogy betwcen the liting of mosquitoes and bad words used towards the rich by common people, who are called "mosquitoes."

2 The seeond time this was sung, Q!o'na kun ("Q!o'tna Point") was substituted for Gilī'sAms. 
A'dAñ g̣ō'ñga nā'g̣ag̣a Égai-ū'kun sq!è'na-i ga tagōóñalYour father's house in Skidegate Point sea-gulls make a noise while xandies ga dAñ gí'dagałgał.

eating in, you get higher all the

time (receivíng

more tattoo-marks, etc.)

In your father's house, in your grandfather's house, in your grandfather's house,

Where Nass Inlet sea-gulls (i. e., the Nass people) make noises as they eat, you, dear, move highly.

In your father's house, where Skidegate Point sea-gulls (i. e., Skidegate people) make a noise as they eat, you get higher (i. e., become a greater chief) all the time.

\section{$5 I$.}

Ayā'ña î́ldjao yaña xî̀'lsîs gañä'ñ gut'tgei dalA'ñ xî̀lldî̂ Becareful, noblemen mine, leavcs like to one you are going qếndaldiasga. to grow.

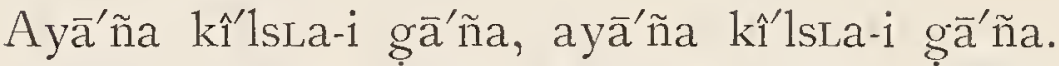
Becareful, chicf mine! Becareful, chief mine!

Be careful, my noble sons! you will grow to one another like leaves.

Be careful, my own chief! Be careful, my own chief!

\section{Eg̣ā'xet gîtîna'-i.}

52.

$\bar{A}^{\prime}$ gua t!a'gagua gagîñañ awā'gua kîlsca-i?

Right for it crying sitting right chief?

here here,

$\bar{A}^{\prime}$ gua t!a'gagua gagîñañ awă'gua kî́lsta-i?

Right for it crying sitting right chief?

here here, 
$\bar{A}^{\prime}$ gua ha'yat xa'nhao djā'sasg̣aña dañ gọótg̣a djî́łdasg̣a

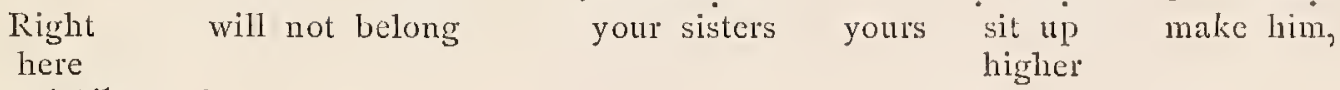
here kî'lsLa-i?

ehief?

Lgă'natsgāãna sq!ens îs ga t'agañałxañg'a'ns gaña'ñ dañ Cousins (yours are) sea-gulls are some make them ery by like you xétga sūisgî́ñ̂gas kî́lsta-i. (like) people stepping on in front say is going ehief. of to be

$\bar{A}^{\prime}$ gua tlaga'gua gagî́ñañ awa'gua kî́lsLa-i?

Right for that crying sitting right ehief?

here here,

Are you crying for it, chief?

Are you crying for it, chief?

Are you crying for your sisters, that you be seated up higher (on a pile of blankets)?

For your cousins, that there be peuple in front of you as numerous as if people made sea-gulls cry, being obliged to step on them, -

For those things are you crying here, chief?

\section{3 .}

Dịga gạa'goaya + , dig̣a gạa'goayat, yē he hēe, To me you eame, to me you eame, ye he he he, Dīga gā'goaya, dīga gă'goaya.

To me you eame, to me yout eame.

Awa'-i L!a'hao dī'ga dīna'̃̃ ga gwaiya'gan.

Mother instead of to me myehild to eame walking.

Awa'-i L!a'hao dī'ga dīna'̃̂̃ gît gwaiya'gan.

Mother instead of to me my ehild ehief's eame walking.

Awa'-i gā'dji wêhe, ${ }^{1}$

Mother of noble mother, family

Awa'-i gā'dji awa'-i (four times).

Mother of noble mother.

1 Equivalent to awa'-i. 
You came to me, you came to me, yē hē hẹ!

You came to me, you came to me.

You came walking to me, calling me "mother," instead of to some one else.

To me my child, who is a chief's child, came walking, calling me "mother,"

Mother of noble family,

Mother of noble family, mother of noble family, mother of noble family, mother of noble family.

Gūgu's gi la gîtgîñ̄ă' $\bar{a}^{\prime}$ ?

What for he is crying like a (or she) noble's son [gît]?

Gūgu's gi la gałgałwa'ñ?

What for he moves around?

Atcī'na-i nā'ga-i gī la kungîña' $\tilde{n}^{7}$ gałgałwa's ahī'gua, etc.

Grandfather the house for he is crying moves about as he is seated.

Why does he cry as a noble cries (i. e., softly)?

Why does he move around as he sits?

He moves around and cries for grandfather's house.

\section{Yā'k $k^{\mathfrak{u}}$ gîtîna $-i$.}

55.

(Words in Tlingit)

Ya'naxē, ya'naxē; $\bar{a}^{\prime} h a o$; ya'naxē, ya'naxe. ${ }^{2}$

Gadjī'djūs dūqał dasgī x̣ūku yana.

his dog

WAgakĩda kAda'ostēdja. 
Haida Equivalent.

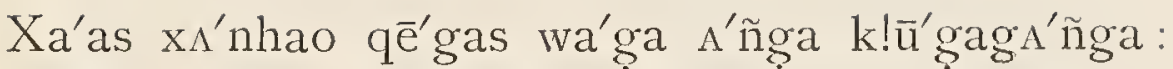

Dogs even when they to them theirs love:

have pups

Wa'ałhao $\Lambda^{\prime}$ ñga ga dī k!ụga'gñ̃.

'That is why mine I love.

Even dogs love their offspring:

So I love mine.

56.

İhïyìyaha, etc.

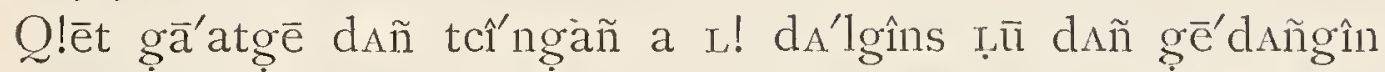
Passage througis to you guests come here when your uscd to danee

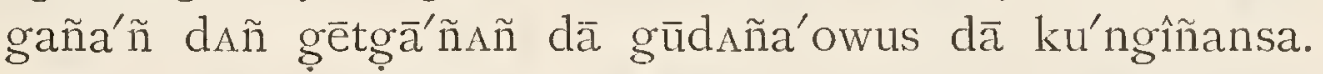
like you to be dancing you thought to be so you cry for it.

Lưū ga gē'dAñgîn gaña' ñ wa'ga gē'daowus.

Olden things were like that way it is now.

times

XA'ldAñ dā'gans xa'nhao gu'lxa lās dā'gax̣ida.

Slaveseven own even abalone- good begin to own.

(common people) shells

İhiya, etc.

İhīyīyahä, etc.

You cry because you want to dance as you used to when guests came through the strait ${ }^{1}$ to you.

It is not now as it was in olden times.

Even slaves (that is, members of other families besides the Yaku gîtîna-i) are beginning to own good abaloneshells.

İhiya, etc.

1 The strait is probably Slidegate Channel. 
Hì hĩ ha hĩ, etc.

Lan L!a ku'ngîñañ.

Stop, how- crying. ever,

Lan L!a k $\bar{u}^{\prime}$ djiū.

Stop, how- and sit ever, down.

Eima'n sqā'laña-i da'ñga gu'tgan kūda'sdiga. (Kind of stowed away yours lies in many caches one after skin)

I'sîñ qā̄łi gut dā kūxiā'ñngwa'ñgasañ.

Again inside you will go round. (of house) the othcr.

Lan a ${ }^{l}$ sg̣a'-ił kîlsta'-i ł q $\bar{e}^{\prime} g a n .^{2}$

Stop your crying, chief I bore.

Hì hì ha hì, etc.

Hì hì ha hĩ, etc.

But stop crying!

Stop and sit down!

Your lims'n blankets lie stowed away in many storehouses.

Again you will go round inside of the house.

Stop crying, chief I bcre!

Hĩ hĩ ha hì, etc.

T̄hì ìhī hī, etc.

Gü'gus t!a'gahas dīnA'ñ kūñgîñ̄áñodigañu?

What for my child sits crying?

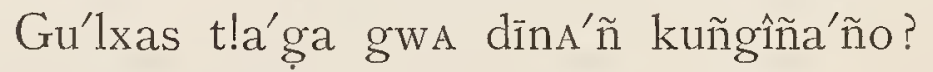

Abalone- for ? my child cries? shells

DAñ gaña'ñ gwa dī kîlsLia'wus qā̃̃ ł qe' $\bar{e}^{\prime}$ gAn.

You like ? I sit a chief, my uncle I bore.

1 Equivalent to ła.

2 The word dina' n̆gan ("my son") is sometimes substituted for $¥ q \mathrm{q}^{\prime} \mathrm{gAn}$. 
Ihī îhī hì, etc.

For what does my child cry?

Does my child cry for abalone-shells?

Like you I sit as a chief, uncle ${ }^{1}$ that I bore?

59.

Lî́ñgua xaldā'ñngañ q!ō'łgẹet [ahìyia]

Why is it your slave elose by,

Hao dā îlgìyā'gañañ dā sūkū'djiwañ?

You want something you say? you cannot get,

DAñ q $\bar{o}^{\prime}$ naga kūdjū'geda qā̃n ł qe'́gAn.

You are too foolish, my unele I borc.

Why do you cry for something that you cannot get, Sitting close by your slave? ?

You are very foolish, uncle I bore.

\section{(For Girls.)}

60.

İhīhīa, îhīhīa (many times).

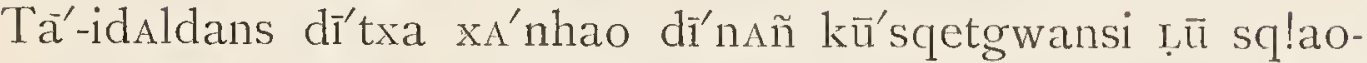
Waves behind even my child looks around whon salmongāns q!ana's at dī'nañ dì gîñ̄óónañgasañ.

berries unripe with my child onc will fool.

Ihìīa, îhīhīa.

Īhīhīa, îhīhīa, etc.

When my child looks around behind the waves even, she will fool me with unripe salmon-berries. ${ }^{3}$ Īhīhīa, îhīhīa.

1 One of the parents' aneestors is reborn: therefore the child is called "uncle."

2 The mothcr calls herself the child's "slave" in jest. An "unclc" is reborn in the ehild.

3 I eould get no clew to the significance of these words, which are evidently partly metaphorical. 
I hīyaha, etc.

Gusta gī'hao dī'nañ kuñgînāàñgañ?

What for my child cries?

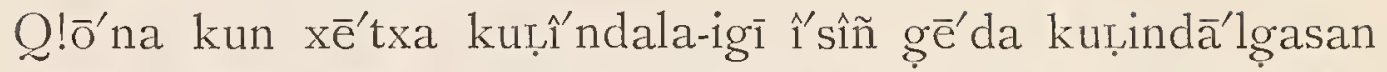
Q!o'na Point in front to pass along by again criesfor she will travel by q!ólgan djā'g̣a? my master's wife?

İhi', etc.

I hĩyaha, etc.

For what is my child crying?

Does she cry to pass along again by canoe in front of Point Q!o'na, my master's wife? ${ }^{1}$

İhí', etc.

$$
\left(\text { For Boys. }{ }^{2}\right)
$$

62.

Ayīhiya, ayīhiya (many times).

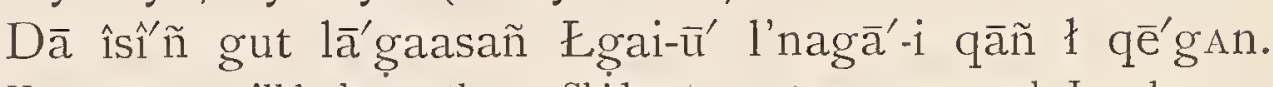
You too will be happy there Skidegate town, my uncle I bore. Ayīhiya, ayī'hiya (many times).

Ayīhhiya, ayī'hiya, etc.

You will again be happy there in Skidegate town, ${ }^{3}$ uncle I bore.

A yī'hīya, ayī'hīya, etc.

1 By saying "master's wife," the singer implies that her child will marry a higher chief than herself. "Passing along again" refers to the former existcnce of the child. Point Q!o'na is near Nasto.

2 Song No. 62 is said also to be used for girls, with some changes in wording

3 The $\mathrm{Ya}^{\prime} \mathrm{k}^{\prime \prime}$ gîtîn $\bar{a}^{\prime}-\mathrm{i}$ are said to have lived originally in the middle of Skide gate village. 
63.

I hīhīa.

Gū'sgihao dā kungiñā'ñ̃wañ?

What you are crying for?

Xā'na-qa'łi gī gua dā ku'ñôiñañ?

Skidegate Inlet for ? you cry?

l'sîñ sta dañ kî́iñawasañ.

Again from you will have news sent around about yout.

I hī'hīa!

What are you crying for?

Do you cry for Skidegate Inlet?

Again from there you will have news spread around about you (when your husband puts up a house-pole).

$$
64 .
$$

Gads'ldiañ, gads'ldiañ (many times),

How great you how great you

Sū'digwañ gī'dadiañ, gī'dadian (last word repeated several

They said belonging to a belonging to a high family, high family

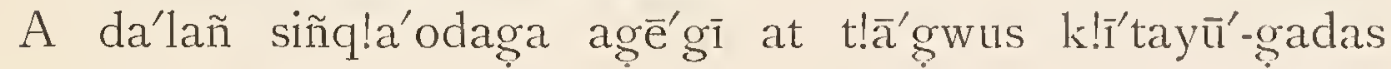
You gambling-stick bag into with copper throw a great one (in exchange wa'at sg̣un gīiāa'diañ sūdî'gwañ. ${ }^{1}$ for services)

with it only belong to a they say. high family,

How great you are, how great you are! etc., They say belonging to a high family, belonging to a high family, etc.

In exchange you throw a great copper into the gamblingstick bag. ${ }^{1} \quad$ They say those with this are the only ones who belong to a high family.

1 This is difficult to translate. Reference is made to a chief of this family who always staked a copper when he gambled, and invariably won. 
$Q \bar{a}^{\prime}$-iał lānas.

(Songs of Qā-i l'nagā'-i.)

65.

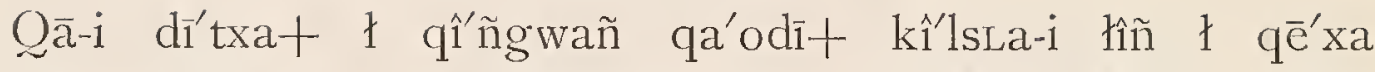
Sea-Lion behind I was looking a while, chief is going I found, (Town) around to be

kA'nxida-i+.

boy just big cnough to walk.

Aiyā'ña, aiyā'ña, kî́lsta-igan.

Take care, take care, my own chief!

Aiyā'ña qî̀ñgètgañ.

Take care, my own master (or chief)!

While I was looking around behind Sea-Lion Town, I found the future chief, a boy just big enough to walk. Take care, take care, my own chief!

Take care, my own master!

66.

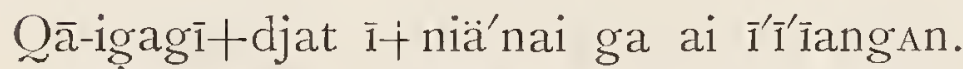

A woman of Qa-i went out and went out and married. marricd,

L! łqaxiastaia'si gu țū qēeda-i hao gao-uła'ñ gua kî́lstaThey are going to call there canoe largest him,

(i. e., chicf's)

is gone in the

chief ig̣a $\bar{a}^{\prime}+$ na.

my own.

One went to Sea-Lion Town to marry.

They were going to call him, but the chief's canoe was gone in the morning, my own chief. ${ }^{1}$

1 An incident in the family history is involved. When they set out to call the chief who was going to marry, the canoe was gone. It was customary for the chief to give a canoe when one of his family married. This is probably referred to. 
67.

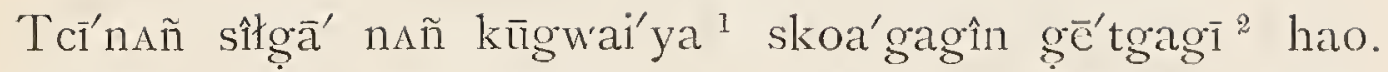

His grand- place some went a long behind was there.

father's one time ago

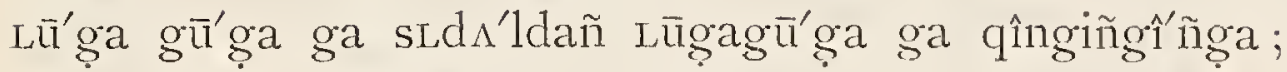

On his canoe planks they put on on his canoe thing is great on the their sides

water;

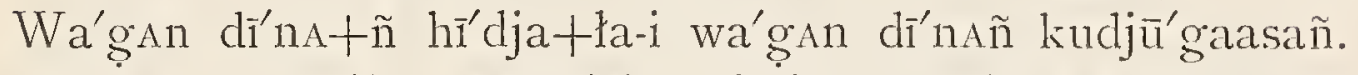
For it my child is a boy (baby for it my child is going to be a word), leader.

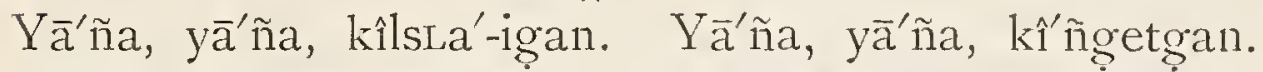

Be careful, be careful, my chief! Be careful, be carcful, my master!

My child is a boy because he is going to do as his grandfather did when one went to his place long ago.

After he had been there, his canoe was so deeply laden (with gifts), that they had to put the weather-boards on it (to increase its capacity);

For it my child is going to be a leader.

Be careful, be careful, my chief! Be careful, be careful, my master!

68.

Gut sī'+łgadaga' ñ $x A^{\prime} n h a o$ kĩ'ga kuq̣eda's at (a) $1_{\Lambda}$

Each right after even names aristocratic with hc

other

kia'gañao gū $\bar{u} \bar{a}^{\prime} g \bar{u}$.

call it sitting thought he would.

Krîlsta'-i kugwé'dalañ ${ }^{3}$ sūwa'ñ.

Chief while walking hither he said.

A'yaña kî́nget gọóñga łiñga'n.

Be careful chief's father is going to be!

Dī'nA ñ ayā'ña q!o'ldjat xă'tga łînğg'n dinna'ñ.

My child be careful, chief-woman father is going to be my child.

\footnotetext{
1 Equivalent to qa'g̣a.

2 Equivalcnt to ge'tgaqa.

3 Kugwétdalañ ("while walking hither") is a low-class word referring to the chief himself.
} 
He thinks he would use high-sounding names, one after the other, (to the others of his own family.) ${ }^{1}$

He says the chief comes walking.

Be careful of the future chief's father!

Be careful of my child, the future chief-woman's father!

(Songs of Kaisun.)

69.

Qoandī'gīni qoandī'gīni kî́lsza-i + ,

There used to there used to chief, be plenty, be plenty,

DAñ nă'ga ga L!a'hao qoa'ndīgînī kîlsca'-i;

Your house in but there used to chief;

Qoandī'gīnīt qoa'ndīgīnì kîlsta' -1 ;

There used to there used to chief;

be plenty, be plenty,

Qoandī'gīnī' qoa'ndígînīi kîlsta'-i.

There used to there used to chief.

be plenty, be plenty,

Lgua' nAñ L! tā'nga hū'gAñgîn kîndā’la wa k!ia'oga gī ła

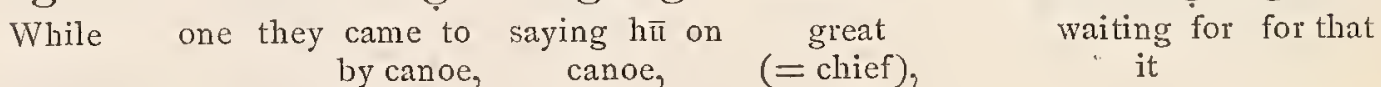
gāgîñ̄ā' ñ-gałgał. you cry and move.

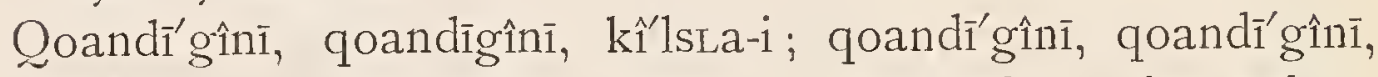
Thcre used to there used to chief; there used to there used to be plenty, be plenty, be plenty, be plenty,

kî́1sLa-i.

chief.

There used to be plenty, there used to be plenty, chief, There used to be plenty in your house, chief;

There used to be plenty, there used to be plenty, chief; There used to be plenty, there used to be plenty, chief.

1 The child is supposed to call others of his family by aristocratic names, and himself by a low one. 
You cry and move about to see them come by canoe (to the potlatch), great chief.

There used to be plenty, there used to be plenty, chief; there used to be plenty, there used to be plenty, chief.

70.

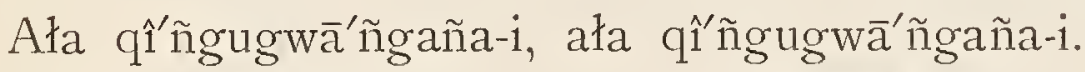

I used to see it, I used to see it.

DAñ nā'gaga ła'ahao t!agōós gōōā'gañas hao gut at

Your house to I copper used for making now each with

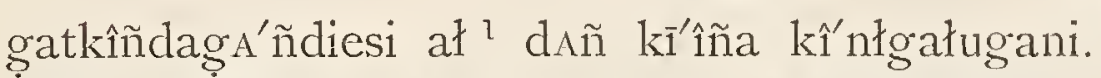

make a noise by knock. with you news of goes about as you
ing against
move about.

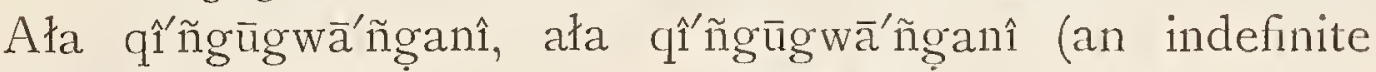
I used to see it, I used lo see it.

number of times).

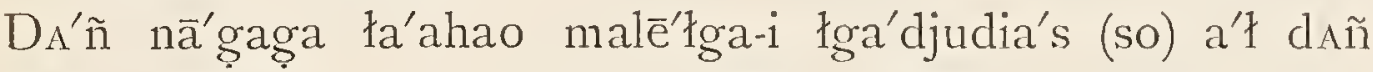
Your house in cranberry-bushes grew of your kĩîña kî̀nłgaługanî.

news of goes about.

Ała kîñngūgwa'ñgañ, ała kî̀ngūgwa'ñgañ.

I used to see it, I used to see it.

I used to see it, I used to see it.

News went about that boxes made of coppers in your house sounded as they knocked one another.

I used to see it, I used to see it.

News went about of cranberry-bushes growing in your house.

I used to see it, I used to see it. 


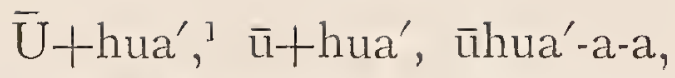
Loftiest one, loftiest one, loftiest one,

DAñ nă'ga ga L!a qoa'ndīgīnī gua kî́lsLa-i.

Your housc in there was formerly plenty, ? chief.

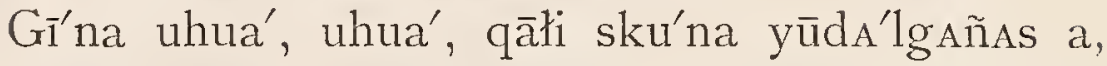

Some- greatest greatest inside (some- smells strongly,

thing, one, one, thing) big

U'hua, $\overline{\mathrm{u}}^{\prime}$ hua, qî́ndal?

Loftiest loftiest mightiest

one, one, one?

Loftiest one, loftiest one, loftiest one,

There used to be plenty in your house, chief.

Does not something big (i. e., a whale) smell strongly in your house,

Loftiest, loftiest, mightiest chief?

\section{2.}

U'hua qînda'l, '̄’hua qiînda'l (ła)

Mightiest chief, mightiest chief,

T!ak!î̀ngāña ga la' qîínwa-i gaatxa'n qî̀ndju,

His own children go to (be born from) without it chief, (to be born) come out of (why not)

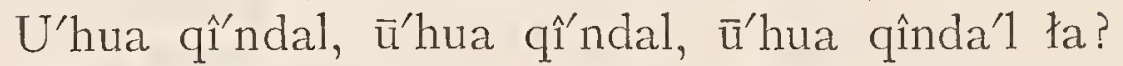

Mighticst chief, mightiest chief, mightiest chief?

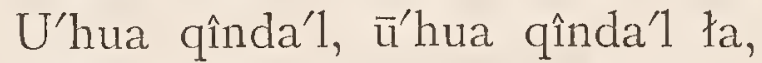

Mightiest chief, mightiest chief,

Gî́sto dañ tū y yư'ga a'wañ qî́ndju,

Who you as large settled chief,

U'hua qînda'1, $\bar{u}^{\prime}$ hua qînda'1?

Mightiest chief, mightiest chief?

I Uhua' is a very high word, only applied to one or two chiefs who attained espccially great power. 
Mightiest chief, mightiest chief,

Why did not he (Gadaga') choose to be born from his own grandchildren (instead of from some of his sisters' children), chief,

Mightiest chief, mightiest chief, mightiest chief?

Mightiest chief, mightiest chief,

Who is settled down into such affluence as he (Gadaga'), ${ }^{1}$ Mightiest chief, mightiest chief?

Nā'-ikun qé $\bar{e}^{\prime}$ gawa-i.

\section{3.}

I'djîsigwa'ns gī dī'nAñ gwa'wañ sū'wasi.

Not a common my ehild he refuses says.

woman at all

Wa'gī dī'+nañ gwa'wañ nañ sū'wasi.

To it my ehild refuses, some one says.

A'ñgạa $x^{\prime}$ nhao inasū'wa gîtî́n-djats xan A'ñga ina'suwē+,

His own just there wants that Eagle-woman yet his says he wants one that one,

A' ñga $x A^{\prime}$ nhao īnasîñ̃gwañ.

His own just there he will marry.

Even a noble woman my child says he refuses.

One says he refuses her.

He wants just that Eagle woman for himself (indicating

a particular one),

Just that one he will marry.

74.

Dja'+djāts L!aha'o 1ā, dja'djāts L!aha'o 1ā.

Women are better (than women are better (than men), men).

Dja'djāts L!a kîñ $\bar{e}^{\prime}$ diasLa.

Women have more property.

1 Gadaga', according to story, was the greatest ehief of the People-of-SeaLion-Town.

4-PUBL. AMER. ETHN. SOC. VOL. IIT. 
Kîlssa-i'gan kîlsLa'-i dañ gẹe'tgwañ axan?

My chiefs (men chiefs you are where? of one's own family)

Women are better (than men), women are better (than men).

Women have more property.

Chiefs of my family, where are you?

(Masset Dialect. ${ }^{\text {) }}$

E'î́llañ q $\bar{e}^{\prime}$ awa-i.

$75 \cdot$

Ẽya hâ hiè', etc.

Qā'gaigaña nă'ga L!ao Skî́lsîs xé'gandigi wa'di kuñgîña'ñ Uncles houses but Skî'lsîs makes a noise for it (he or she) is uga'-i.

Wa'di kū'djiwa e éya hâ hīe, etc.

For it sits greatly.

$\bar{E}$ ya hâ hiē', etc.

But he (or she) is crying for the noise Skî'lsîs (now reborn) makes in his uncles' houses (at the potlatch).

For it he sits greatly.

$$
76 .
$$

Gīsta L!ao daga'sado sî́liya dā skA'ndañ kudjū'gi[gēêt] Who but will own it after it you are crying are sitting dō'ne ałdjī'wai? ${ }^{2}$

younger are sitting? brother

But do you sit crying over who will afterwards own it, younger brother of good family?

1 In the songs the Masset catch \& is strengthened to Skidegate g.

2 Or $k \bar{u}^{\prime}$ djiwai. 


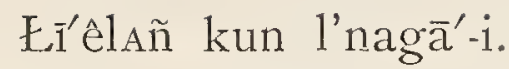

77.

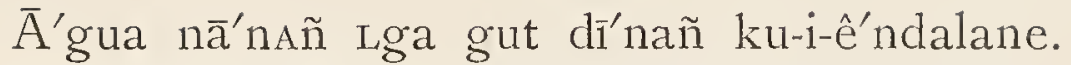

It was his grand- land upon my child walks (a proud word). mother's

Wa'gan st!a'ga kudja'oanē.

For it his foot is dear.

Gam ła ku’ñgînañ Añ.

Not you cry (excl.)!

My child walks proudly upon his grandmother's land.

His dear foot is for that (i. e., to walk on it).

Do not $\mathrm{cr}^{-} \mathrm{y}$ !

78 .

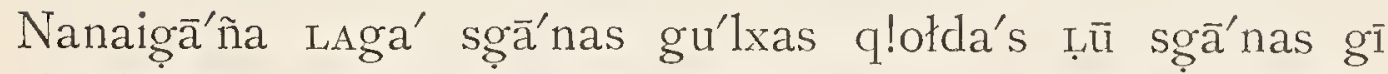

Grandmothcr's land supernatural abalone- stole when supernatural to łì kiä'gañgîn.

I called.

Gam gîn gu dē gudA'ñañ hai.

Nothing I wish to eat (?) now.

When the supernatural beings stole abalone-shells from grandmother's land, I called to the supernatural beings. Nothing I wish to eat (?).

79.

Tcî́nAñ lū'ga giū'gulaga, tcínnñ̃ lū'ga giū'gulaga.

Grand- wave listens for, grand- wave listens for.

Stather's

After but grand- sea upon goes along stopping often on

it father's the way (upon the water). 
(He) listens for grandfather's ${ }^{1}$ wave, he listens for grandfather's wave;

But afterwards he goes along upon grandfather's sea, stopping every now and then on the way.

80 .

$\bar{A}^{\prime}$ gua nă'nAñ Lga gut ku'łg̣ałguña'-i g̣an wag̣a'n sL!a'gA Here is hergrand- land upon walking about for for it use (your) kudjā'wan. ${ }^{2}$ dear.

Use your hands, my dear, to walk about upon grandmother's land.

\section{$8 \mathrm{I}$.}

Gia'gañ L!ao yuā'ndaga-i, gia'ĝ̣ñ L!ao yuā'ndaga-i. My crests how- are very large; my crests, how- are very large. (or figures), ever, ever, Hao q!a'lîñs yuā'ndaga-i, hao q!a'lîñas yuā'ndaga-i. This image is very large, this image is very large. Gia'g̣añ L!ao yuā'ndaga-i, hao q!a'lîñas yuä'ndaga-i. My crests, how- are very large, this image is very large.

Ła L!ao gaogē'łdasañ, ła L!ao gaogếł łasañ.

I them will put away, I them will put away. Hao q!a'1Añas yuā'ndaga-i, hao q!a'lÃ̃ns yuā'ndaga-i. This image is very large, this image is very large.

My crests (as carved) are very large, my crests are very large.

This image is very large, this image is very large. My crests are very large, this image is very large. I will put them away, I will put them away. This image is very large, this image is very large.

1 The "grandfather" here referred to is probably Raven.

2 Kudjā'wan is also a "high word" for "to sit." 
82.

A LAga-i yuku'ndjudasi î'ñgut sgạa'nas $\bar{u}$ dala'̃̃ yếdadaThis land is a point (Rose Spit) on $\begin{gathered}\text { supernatu- those you left. } \\ \text { ral beings }\end{gathered}$ dìgīnī.

Supernatural beings used to leave you on this point of land (i. e., Rose Spit).

SL!ê'ña lā'nas.

83.

Hawa'nō qō godañ Skî̀lsîs l'nagă'-i.

Still stands Skî́lsîs's town.

Gam $\nmid$ dì'gu ku'ñgîñañañ.

Not upon me cry. (my knees)

Skî'lsîs's town still stands.

Do not cry upon my knees!

84.

Yên dañ î́skudals Lū gam $ł$ dī'gu ku'ñgîñañ hañ.

Truly you are chief (or if not you on my cry!

Dì gwa ga lgaiqendigwa'ñus.

I am not rich.

If you are truly a chief (reborn), do not cry upon my knees!

I am not rich. ${ }^{1}$

1 The child is scolded as being a reborn chief, and too great to cry. 
85.

Gū'gus t!ao dañ sū'kudjiwañ gia'ga t!a'gwa?

What for you are crying? things for?

(clothing)

WAsk!iên a'ña dAñ gia'nda kudjū'asañ.

But yours you shall wear chief (or "dear").

For what do you cry, chief (or dear)? For clothing? You shall wear it, chief (or dear).

86.

Nañ gẹest' dī'na qoga'-iwas țū naas gadōó dīna kü'sqedAOut of hishouse mine goes out when, house around mine will walk gwañasañ.

and look.

Îlldjao dA'ñał kuda'ltc!aasañ.

Chief with my dear will enter. (or rich man)

When my child goes out of his house, he will walk around among the houses and look about.

With chiefs (only) my dear will enter.

Skî́daoqao.

$$
87 \cdot{ }^{1}
$$

Dañ tcîn łkliä'nao dan da qä'tcū kū'udañ.

Your grand- by stick (cedar you for is looking chief's son father trunk used for (or "dear") canoe)

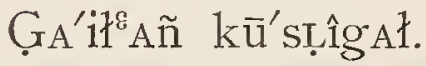

To yourself go straight up.

Your grandfather's canoe is looking for you, dear. Go straight up to it.

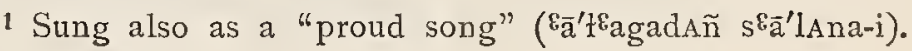


88.

Ula'man gīiłgīgasLas lū tc!a'Añ gut ku'sgetgîñn. Ula'man is on the sea when his canoe upon the captain (in sight) companions looked about.

A $ł \operatorname{agA}{ }^{\prime} \tilde{n}$ kî́lsLia kudjǘda.

Make yourself a chief's son, dear.

Haiya kî'lsca-i, haiya kî́lsca-i, ha'oîsîn kî'lsLa-igan.

Now chief, now chief, again chief.

When ULa'man ${ }^{1}$ lay in sight on the sea, the captain looked about upon his companions (allowing them to relax their efforts).

Make yourself a chief's son, dear.

Again he is a chief, is a chief, is a chief.

1 Ula'man is a long, low hill near Rose Spit, generally the first sighted by canoes from Port Simpson and neighboring places in the Tsimshian country. The mother is probably thinking of the time when her child will come home from trading with the Tsimshian. A third song, which I was unable to obtain in Haida, tells in the first verse about intermarriages between the young men of the Skî'daoqao and young women of the StA'stas; in the second verse, of intermarriages with women of the Gîtîns of Masset. 


\section{II. - MOURNING-SONGS. \\ (Ki̊łdjao qaga'n or S'ai'ga s'alnña.) \\ (Masset Dialect.) \\ Yak ${ }^{u} \overline{l a}^{\prime}$ nas.}

89.

Hao gua dã̃ qā'gułagī.

? you are going down.

Djīgōes gu qagūłaga kuda’1.

Sun there is going down, dear.

Are you going down?

The sun there is going down, dear, ${ }^{1}$

90.

Qeda'o gu wa qeda'o gu wa, gada'-i łī qēga'na. War men : lrilled ${ }^{2}$ war men ? lilled dear daugh- I bore.

Qēda'o gwa wa, qēda'o gwa wa.

War men ? killed war men ? killed you, you.

Did warriors kill you, did warriors kill you, dear daughter that I bore?

Did warriors kill you, did warriors kill you?

1 The dead man is likened to the sun.

2 Literally, "did." 
9 I.

QoangẹédAñ, qoangēédañ, qoya'sga

It becomes too it becomes too dear. much, much,

Qoangẹe'dAñ, qoange $\bar{e}^{\prime} d A \tilde{n}$, qoya'sga.

It becomes too it becomes too dear. much, much,

Qoangë'dAñ, qoangēédAñ, qoya'sga.

It becomcs too it becomes too dear.

much, much,

Qoangẹe'dAñ, qoangẹe'dAñ, qoya'sga.

It becomes too it becomes too dear. much, much,

It becomes too much, it becomes too much, dear. ${ }^{1}$

It becomes too much, it becomes too much, dear.

It becomes too much, it becomes too much, dear.

It becomes too much, it becomes "too much, dear.

SL!ê'ña lā'nas.

92.

Gū'stas lī'nañ a q!ē'nañ ana'ñ xī'ladīgwañdañ?

What (nothing) myself certain shall use for medicinc? thing

Gǘstas Lî́nañ a q!ē'nañ ana'ñ xî́ladīgwañdañ?

What (nothing) myself ccrtain shall use for medicine?

Q!ē'nañ a dī Ałkū'skīdēgwañ.

For myself I have nothing.

Qoya's dañ xañhîña'-i.

Dear your face.

What medicine shall I use (in my affliction)?

What medicine shall I use?

I have nothing to comfort me.

Your dear face (I long for).

1 That is, my grief is too great to bear. 


\section{$93^{1}$}

Qo-ēs LLî́ñalañ 'a-i $ł$ kusī't!ał.

Clouds open with through, look down. your hands

DAñ łū'yîña-i dañ XA' ñîña-i.

Your body all your face all (we wish to see).

Parting the clouds with your hands, look down (from Tā'xet's house).

We wish to see your body and your face.

$$
94 .^{2}
$$

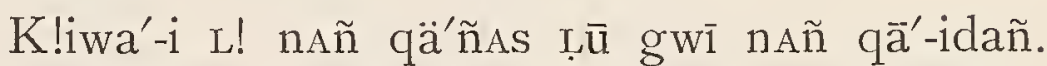

The trail but one could see if upon one could go, (of the dead)

Gwai'yē dañ a’łdjiwa-i.

Elder brother, your whole body.

If I could see the trail (of the dead), I would enter upon it. Elder brother, (I want to see) your whole body.

$$
95 \cdot^{3}
$$

Gîn st!ē'dīguña-i gwai'yai,

Some- makes my heart elder brother,

thing sick (or very

(= your) sad),

Gîn st!ē'dīguña-i.

Some- makes my heart

thing sick.

Something (i. e., the loss of you) makes my heart sick, elder brother.

Something makes my heart sick.

1 Sung only by the women of this family.

2 Sung by a man named Skîlqoe'tas for his brother.

3 Sung by the same man as Song 94 . 
96.

Ha'k!un dAñ gudA'ns k!iên gu gam qe'id LAk!ala 'a dĩ Like that you thought although ? not tree shelter of in dAñ q!a'odañ-ūdja.

you seated me?

If you thought so (i.e., if you chose to die), why did you not seat me in the shelter of a tree? ?

Tās lā́nas.

97.

[This was composed by Qadjiq $\bar{o}^{\prime} k^{\mathfrak{u}}$ when his niece was drowned in Q!a'nan River, and her body could not be found.]

$$
\begin{aligned}
& \text { Gū'stas, gī } ł \text { da'-indAgwañgAñ? } \\
& \text { What for I poor one searching? } \\
& \text { Hā'djadia nă } \bar{a}^{\prime} \text { da-i. } \\
& \text { Alas! my nicce. }
\end{aligned}
$$

For what am I, unfortunate one, looking?

Alas! my niece.

\section{T!ōłkla gîtanā'-i.}

$$
98 .^{2}
$$

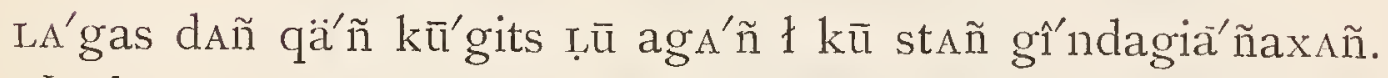
Land you see, beloved when your- $\begin{gathered}\text { dear two if you made in canoe. } \\ \text { self, (or chief), }\end{gathered}$

If you had seen land, beloved, you would have saved yourself, dear. ${ }^{3}$

1 The last part of this is metaphorical. It means, "Why did you die so suddenly ?"

2 Sung by the wife of one lost at sea.

3 This is merely the sense of the Haida. 
Family Doubtful.

99.

GAm ła íl'L!dA qe' g̣axañgo (repeated over and over).

Not you at us look.

Do not look at us.

$$
\text { IOO. }{ }^{1}
$$

Dalı' ñ gu kî́lsta-us dī L!ao gam kîllstasta dī gudA'ñhañgan. Your ? voices are I but not have a tired I want to. tired, voice

Your voices are tired, but I do not want to have a tired voice (i. e., I do not want to cease wailing).

1 Perhaps a song of the LiêtAñ qe'awa-i. 


\title{
III. - MISCELLANEOUS SONGS.
}

\author{
(Masset Dialect.)
}

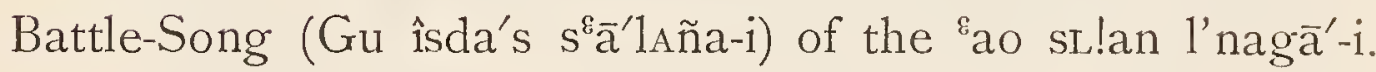

IOI.

A'gua Skî́lsîs l'nagă'-i 'ai'ya gagagō'das hō.

Here Skî́'lsîs's town lies.

DAñ gua gứla dō'na-i (repeated four times).

You ? think it younger

good brother?

Here lies Skî́lsîs's town.

Are you pleased with it, younger brother? ${ }^{1}$

Battle-Song sung in Tsimshian.

$\mathrm{IO} 2 .^{2}$

[Sung around the head of an enemy raised upon a pole.] You Tsimshian people are foolish. Are you like coppers?

1 The "younger brother" is perhaps a captive or an opponent in battle.

2 I was able to obtain only the translation of this song.

3 Because they were fearless in battle.

$[6 \mathrm{I}]$ 
Battle-Song of Women.

IO3.

SSong by women during the absence of their husbands with a war-party.]

Sk! A $^{\prime}$ ga-o $t$ ! a'ēt qō'nagañ.

Sk!A'gao, this killed many people.

Sk!A'gao killed (and enslaved) many people.

Song used by All Families in making Peace

(Ga $\left.1 \bar{a}^{\prime} s^{8} a^{\prime} 1_{A n ̃ a}-i\right)$.

I 04 .

Yêł dī tāda's țū q!e'nañ dī u'nsatsgaiya'ndō.

Ravenme ate if myself I would not know.

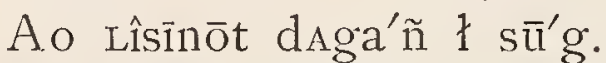

Now first time for myself I am singing.

If Raven had eaten me, ${ }^{1}$ I would not know myself.

Now for the first time I am singing to myself.

Song used by the 'ao sL!an l'naga ${ }^{-1}-1$ in making Peace.

$$
\text { IO5. }
$$

Xấ'ța gwai'yē gọółg̣ał q!ē'aosgiên.

Haidas' island green has become.

The island of the Haida has become green (i. e. the hats have appeared as when spring comes and the foliage turns green.)

1 "Being eaten by Raven" seems to mean being lkilled in war. 
Songs of Derision.

[Songs of this kind were largely in Tsimshian. The following is a translation of one of them, used in making fun of a poor man who pretended that he was a chief.]

Io6.

Laugh at the chief! for, although he is a chief, he has no rattle in his hand. 

